\title{
Timing of Svecofennian crustal growth and collisional tectonics in Åland, SW Finland
}

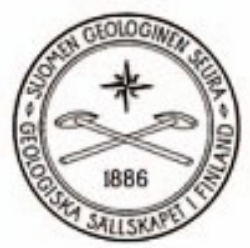

\author{
CARl Ehlers ${ }^{\text {I) }}$, Torbjörn Skiöld ${ }^{2)^{*}}$ and Matti VAasjoki ${ }^{3)}$ \\ ${ }^{1)}$ Department of Geology and Mineralogy, Abo Akademi University, \\ FIN-20500 Turku, Finland \\ ${ }^{2}$ Swedish Museum of Natural History, Box 50007, SE-104 05 Stockholm, Sweden \\ ${ }^{3)}$ Geological Survey of Finland, P.O. Box 96, FIN-02151 Espoo, Finland
}

\begin{abstract}
In an effort to quantify the time parameter in the tectonomagmatic evolution of what has been called the Southern Svecofennian Arc Complex (SSAC) of SW Finland, advanced radiometric dating techniques have here been applied to rock groups of key importance in that area. In this paper we report the results of 131 high-resolution ion microprobe spot analyses (SIMS) of zircons, and 33 measurements using isotope dilution mass spectrometry (ID-TIMS) on zircon, monazite and titanite, and employing both large-sample multi-grain as well as single-grain techniques.

The Torsholma area of the Åland archipelago, situated between southern Finland and central Sweden, is a key structural area significant to resolve the time dimension in Svecofennian tectonics. There a collage of imbricated rock slabs was formed by tectonic shortening representing the culmination of large-scale penetrative Svecofennian deformation. Another structurally significant feature investigated is the South Finland Shear Zone (SFSZ) that transects the southwest-Finnish archipelago and further east follows the southern coast of Finland. This shear zone forms the southern limit of the c. 1830 Ma Late Svecofennian Granite and Migmatite Zone (LSGM) and also features deformations of a later stage when the considered region of Svecofennian crust was consolidated.

The obtained age results and their tectonic analysis can be summarized as follows. The Enklinge volcanic sequence ( $1885 \pm 6 \mathrm{Ma}$ ) is within error limits coeval with the intrusion of abundant early-kinematic gneissose granodiorites whose average age of I $884 \pm 5$ Ma marks the formation of new crust in this region. Some of these geisses contain a significant amount of 2000-2080 Ma zircon. Although many Svecofennian granitoids are known to contain heterogeneous zircon populations, mainly formed c. $1890 \mathrm{Ma}$ ago but also containing an inherited component, the Kökar gneiss is, to the best of our knowledge, the first case where inheritance from c. 2030 Ma sources has been unequivocally demonstrated in a syntectonic Svecofennian intrusive rock.

At Torsholma, granodiorites (1879 $\pm 6 \mathrm{Ma}$ ) have similarly intruded the supracrustal series, but there they were later metamorphosed into granulite orthogneisses. The mesoscopic recumbent folds and subhorizontal schistosity of these gneisses were transected by a set of steep amphibolitic dykes indicating an episode of extension. During a preceding stage, these gneisses had been sandwiched like an allochthonous slab unit between the supracrustal rocks. Younger sheet-like granodioritic intrusions

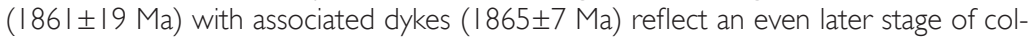
lisional thrusting. Altogether this tectonic evolution lasted for approximately $15 \mathrm{Ma}$ (c. | $875-1860 \mathrm{Ma}$ ) and records a period of significant deformations during the Svecofennian orogeny. Monazites and zircon rims yield concordant $\mathrm{U}-\mathrm{Pb}$ ages of c. $1830 \mathrm{Ma}$. This is in agreement with previously obtained ages of late Svecofennian granites and migmatites in the LSGM zone in S Finland.

Weakly deformed pegmatites and even-grained granite dykes were emplaced $1790 \pm 6 \mathrm{Ma}$ ago and intersect the other rocks of the area. They characterize the vaning stages of shearing along the northwestern part of the SFSZ, and the establishment of a consolidated crust where deformation was about to cease by this time.
\end{abstract}

Key words: crust, tectonics, plate collision, granites, granodiorites, gneisses, rhyolite porphyry, metadiabase, absolute age, Paleoproterozoic, Åland Province, Finland 


\section{Introduction}

Late-Palaeoproterozoic Svecofennian orogeny in the Baltic (Fennoscandian) Shield was part of a worldwide process (cf. Hoffman, 1989) that often caused amalgamation of newly formed juvenile crust with ancient proto-cratons, simultaneously regenerating their border areas. Judging from geochronological and geochemical data, similarly timed episodes occured in several now separate parts of the Laurentian craton, Greenland and the Baltic Shield. It has been discussed to what extent these shield areas were part of a pre-Rodinian mosaic of continental crust (Karlström et al., 2001; Elming \& Mattsson, 2001).

The metavolcanic and metasedimentary belts in southern Finland have been considered to represent parts of two major arc complexes; the Central Svecofennian Arc Complex (CSAC) and the Southern Svecofennian Arc Complex (SSAC), which are separated by an inferred suture zone (Lahtinen, 1996; Nironen, 1997; Nironen et al., 2000; Väisänen et al., 2002). While the crustal evolution of the Baltic Shield is fairly well constrained when it comes to the general framework of crust formation and radiometric ages, the detailed kinematic characteristics of the different tectonic and metamorphic phases of evolution are less well known. Recent works by e.g. Lahtinen \& Huhma (1997), Nironen (1997), Elliot et al. (1998), Korsman et al. (1999), Vaasjoki et al. (2001), Nironen et al. (2002) and Väisänen (2002) have considerably improved our understanding of these events. Zircon ion microprobe studies by Huhma et al. (1991) and Claesson et al. (1993), and later by Lindh et al. (2001), Väisänen et al. (2002), Rutland et al. (2001a, 2001b and 2003), and Weihed et al. (2002), indicate the existence of a pre$1.95 \mathrm{Ga}$ Palaeoproterozoic continental crust in different parts of the shield. Nironen, et al. (2002) and Lahtinen et al. (2004) have presented "a new tectonic model" based on integrated research on the early development of the Bal-

\footnotetext{
* Corresponding author

e-mail: torbjorn.skiold@nrm.se
}

tic Shield involving a number of pre-2.0 Ga micro-continents accreted to the Archaean domain 1920-1880 Ma ago.

The archipelago of SW Finland represents a well exposed segment of the Svecofennian crust with a demand for modern age determinations. In the present study we recognize zircons representing such pre-2.0 Ga crust as well as minor Archaean influence in the Åland islands. We compare milli-gram and micro-gram zircon isotope dilution mass spectrometry with nano-gram technique on homogeneous zircon domains within single grains. Our new isotopic data aim at timing the Svecofennian, c. 1900 $\mathrm{Ma}$, compressional/transpressional stages. In particular, we constrain the time of the allochthonous thrusting at Torsholma, Åland (Fig. 1), which represents the collisional stage of the Svecofennian tectonic evolution in that region. The timing of later movements within the regional ductile South Finland Shear Zone (SFSZ, Torvela et al., 2003) is monitored by recrystallized monazite and titanite, and by the dating of zircons in coeval granitoid intrusions.

\section{General geology}

The Svecofennian components of the Baltic Shield comprise supracrustal continental rock accumulations atop and along the borders of the Archaean proto-craton as well as successively accreted island arcs and magmatic additions. The diverse formation processes have previously been discussed within the context of cyclic orogeny but more recently as repeated plate-tectonic interactions of crustal segments, which are considered to have taken place during the time interval between 2.0 and 1.75 Ga ago (cf. discussions in Gaál \& Gorbatschev, 1987; Nironen, 1997; Nironen et al., 2002). In its present form, the crust constitutes domains with slightly different geochemical and lithological signatures, suggesting sutures between different sub-terranes (Ehlers \& Lindroos, 1997; Lahtinen et al., 2002; and references therein). 


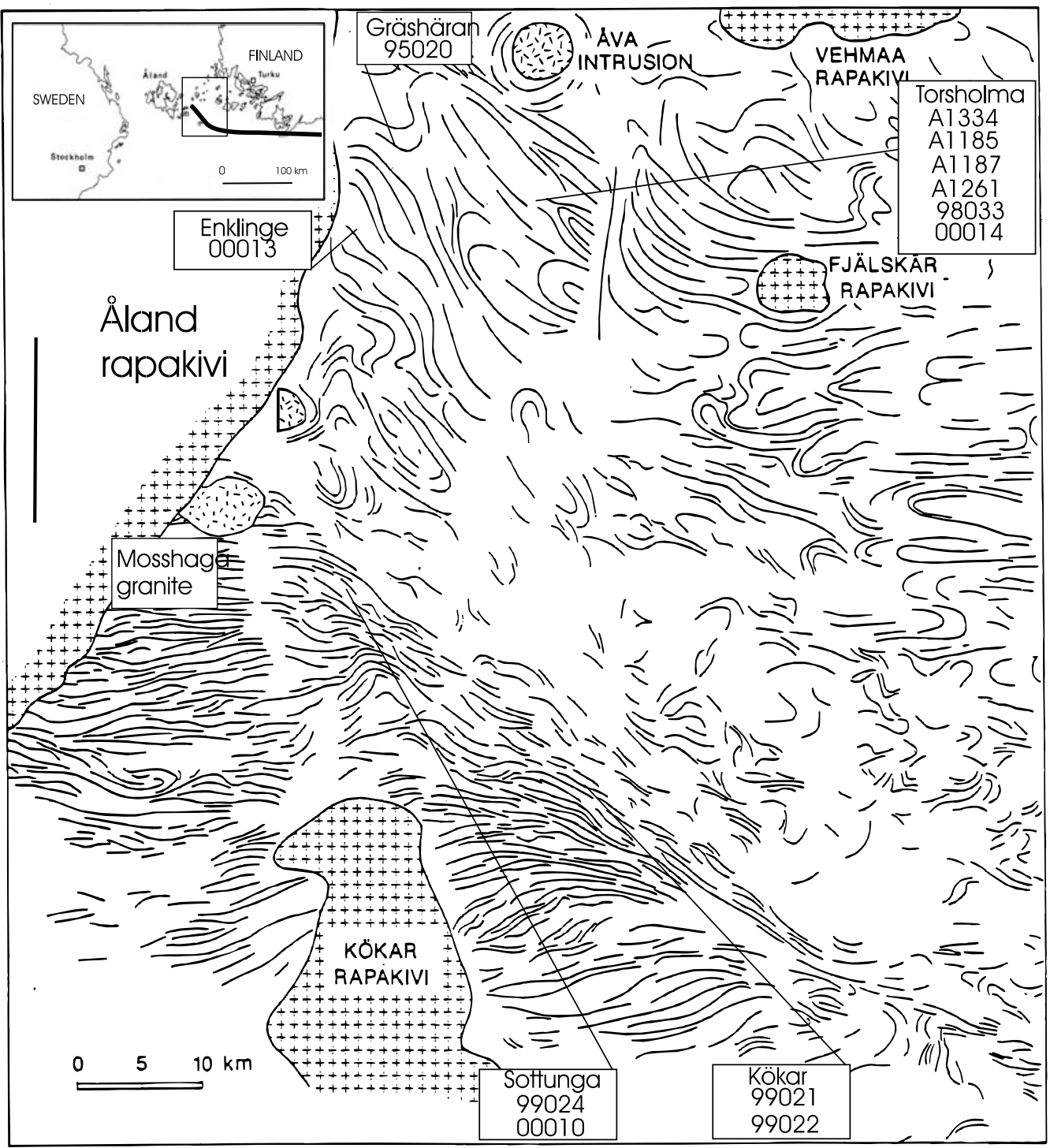

Fig. I. The map sketches foliations in rocks of the Åland archipelago of SW Finland. Sample numbers and localities are inserted. The dextral South Finland Shear Zone (SFSZ) transects the area in a NW direction. North of the shear zone the bedrock consists of structurally overturned gently dipping migmatites and supracrustal rocks forming a "dome-and-basin" structure. South of the shear zone granodioritic gneisses appear with sparse supracrustal inclusions. Early phases of post-kinematic roundish granite massifs like Mosshaga are transected by c. $200 \mathrm{Ma}$ younger Rapakivi granites.

The geological structure of SW Finland is dominated by early subaqueous mafic and felsic volcanic rock sequences which were overturned/ inverted and thrusted towards the west and the northwest (Lindroos et al., 1996). They constitute a region of subhorizontal slabs with sub- parallel transposed layering and early schistosities. The mainly supracrustal rock sequences were subsequently intruded by sheets of early-kinematic granodioritic and tonalitic rocks. Later metamorphism and intrusion of younger migmatitic granites belonging to the c. 1830 
Emplacement age of deformed orthogneiss
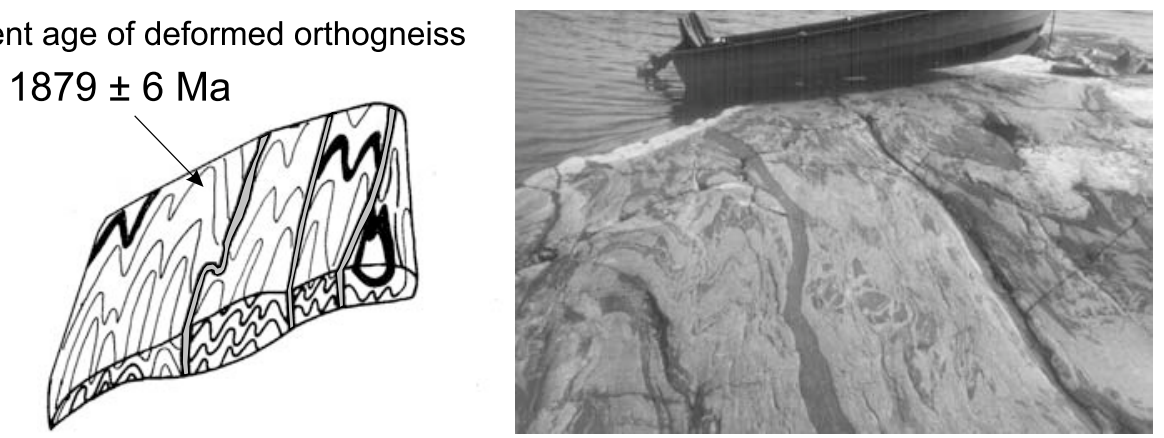

(1) Deformed gneiss intruded by amphibolitic metadiabases

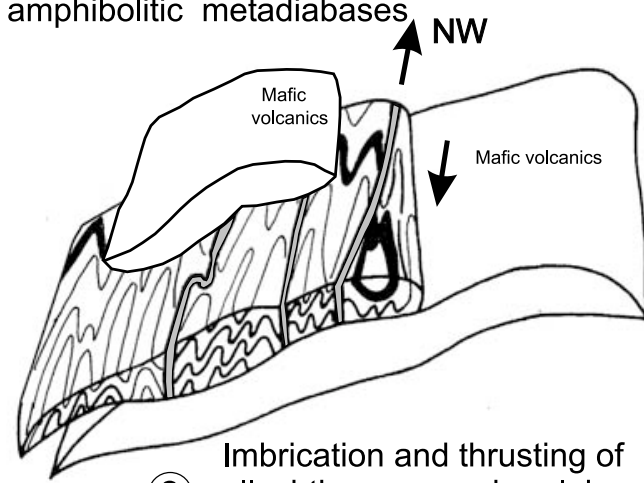

Approximate timing of imbrication and collision based on the geology of Torsholma area

(2) allochthonous gneiss slab, ca. $1860-1875 \mathrm{Ma}$ arrows indicate direction of movement.

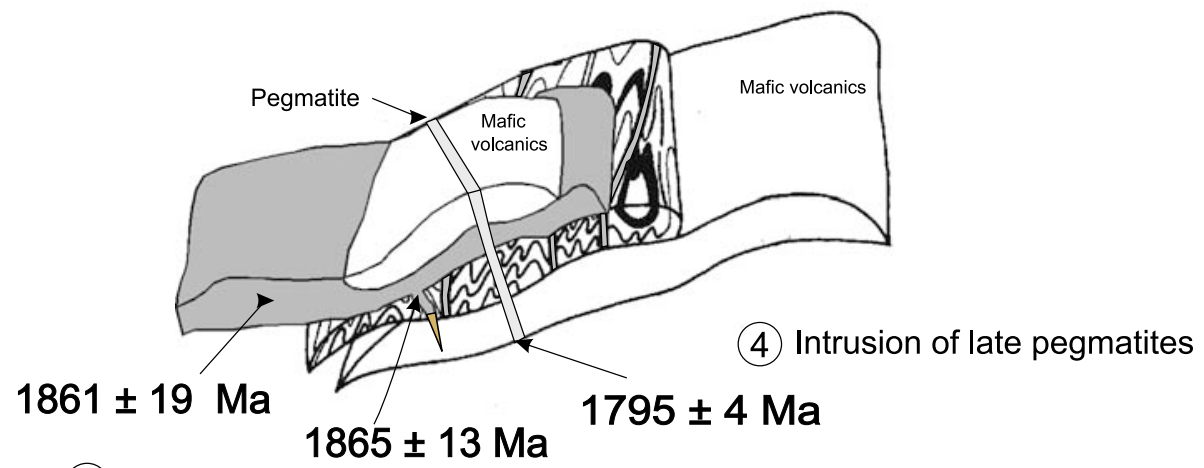

(3) Intrusion of granodiorite sheet

Fig. 2. A schematic history of the rocks and a compilation of dated events in the Torsholma area, SW Finland. The dated samples indicate that most of the structural history with early recumbent folding, extension of the crust, and subsequent thrusting and sandwiching of the gneiss slab took place over a rather short period of time, approximately $15 \mathrm{Ma}$. The ages are from this study. 
Ma old zone of Late Svecofennian granites and migmatites (the LSGM zone of Ehlers et al., 1993) dominate the southern coast of Finland. All these structures are cut by the large SFSZ (Ehlers \& Lindroos, 1990a), while gneissose granodioritic and granitic rocks reappear further to the south (Suominen, 1991; Fig. 1).

\section{Regional geology of the investigated terrains}

Mapping and geological correlations in the area have been carried out since the early years of the twentieth century, chiefly to produce regional geological maps and map descriptions. In the southwestern archipelago of Finland, J.J.Sederholm's (1934) classical account of the geology of the Aland islands is rich in excellent observations and geological sketches of outcrops. Later contributions by Edelman and Jaanus-Järkkälä (1983), Edelman (1979), Ehlers and Lindroos (1990a and b) describe various aspects of the regional geology of the areas considered in this paper.

\section{I. The Torsholma area}

The Torsholma area is characterized by gently dipping sheets of volcanic rocks and granitoids, tectonically stacked atop of each other, and separated by tectonic or intrusive contacts (Fig. 2). A thin slab of strongly deformed granulite-facies ortho-gneiss, that appears to have intruded layers of earlier supracrustals and showing multiple stages of deformation, is sandwiched between a sequence of gently dipping and folded mafic volcanics (Ehlers et al., 1993). It is the oldest rock in the area, and at the time of original sampling an age in excess of $1900 \mathrm{Ma}$ was considered possible. The gneisses are cut by a set of steep amphibolitic metadiabase dykes which is later than the sub-horizontal early deformation in the gneiss slab (Fig. 3). The appearances of these rocks are visualized in Fig. 2:1 where folded mafic bands are cut by relatively undeformed metadiabase dykes. The dykes are present only in the gneissic slab which subsequently was sandwiched in between the sheets of amphibolitic volcanics (Fig. 2:2). An intrusive sheet of granodiorite, less deformed than the surrounding country-rock gneisses and without any traces of metadiabase dykes (Fig. 2:3), occurs between the deformed gneiss slab and the amphibolitic volcanic outlier. This sheet records deformation indicating thrusting towards the northwest. We consider therefore that the sheet-like granodiorite was emplaced during a relatively late stage in the creation of this tectonic collage.

The metadiabase dykes cut the deformed gneiss slab at a high angle (Fig. 3). This may be taken to indicate a phase of crustal extension and intrusion of basaltic dykes which, in turn, post-dates most of the early deformation but pre-dates the stacking of the slabs. The entire collage of juxtaposed rocks was later migmatized and intruded by late Svecofennian granites dated at c. $1830 \mathrm{Ma}$ from several localities in southern Finland (Suominen, 1991). In order to establish the timing of the episode of stacking and sandwiching of the different rock slabs, we have sampled the allochthonous gneiss slab (samples A1334, 98033), the intrusive sheet of granodiorite (A1261, A1187), as well as one of the metadiabase dykes (00014). An essentially undeformed cross-cutting pegmatite (Fig. 2: 4) represents a post-stacking stage of intrusion (sample A1185).

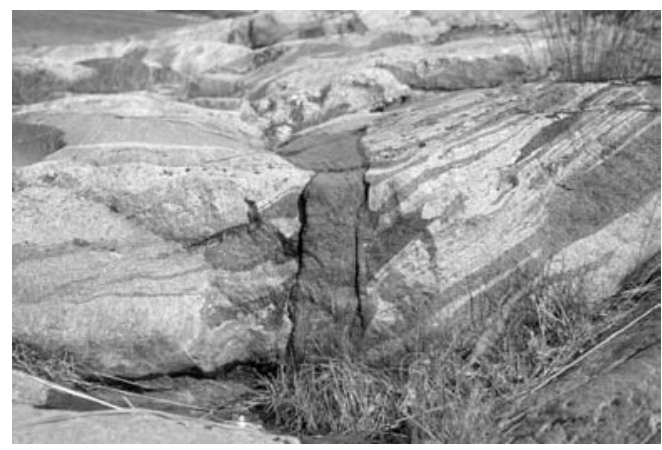

Fig. 3. Amphibolitic meta-diabases have intruded previously overturned and strongly deformed gneisses with subparallel transposed amphibolitic layers. 


\subsection{The Enklinge area}

The Palaeoproterozoic volcanic successions in the SW Aland archipelago are well represented on and around the island of Enklinge. They consist of subaqueous sequences of mafic and felsic volcanic rocks with primary structures representing lava pillows and pillow breccias (Ehlers, 1976; Ehlers \& Lindroos, 1990a). Higher strata comprise thin marble layers followed by rhyolitic extrusions. Related in time but somewhat later are granodiorite intrusions surrounding the volcanic rocks at Enklinge, and there are also intrusive dacitic quartz-porphyritic dykes in the volcanics. Chemically, the dykes are identical with the surrounding granodiorites but differ quite clearly from the extrusive rhyolites (Ehlers \& Lindroos, 1990b). We have carried out SIMS analyses of zircons from the rhyolite on Enklinge (sample 00013) and from the granodiorite sampled at the small islet of Gräshäran (sample 95020) north of Enklinge.

\subsection{The South Finland Shear Zone at the Sottunga and Kökar islands}

The prominent South Finland Shear Zone (SFSZ; Fig. 1) can be traced a couple of hundred kilometres along the southern coast of Finland. In the southwestern archipelago, it closely follows the southern margin of the c. $1830 \mathrm{Ma}$ old belt of Late Svecofennian Granites and Migmatites (LSGM, Ehlers et al., 1993), but most of the dextral shear deformation is found in the surrounding c. $50 \mathrm{Ma}$ older granodiorites.

Subsequently, the SFSZ was intruded by even-grained granite dykes which register the latest phases of shearing along that zone. One sample of these late granite dykes (sample 00010), and three samples of the deformed gneissose granodiorites (samples 99021 and 99022 from Kökar, and sample 99024 from Sottunga; Fig. 1) were sampled along the SFSZ. The early phases of shear deformation have not been dated. From the island of Sottunga, a strongly banded, deformed granodiorite was selected. Another sample was collected from the matrix between fragments of boudinaged and brecciated mafic enclaves further southwards on the island of Kökar (Fig. 1). Finally, a deformed layer of granodiorite with a strong gently dipping linear structure was sampled on the northwestern shore of Kökar. That granodiorite forms a gently dipping layer, a few metres thick, in a westwards thrusted and openly folded stack of thin layers of metasedimentary rocks embedded in deformed granodiorites.

All these samples were collected with the double aim of determining the intrusion age of the granodiorite as well as the age of the SFSZ deformation.

\section{Analytical Procedure}

Mass spectrometric analyses were carried out using two types of techniques: (1) Thermal Ionization Mass Spectrometry (TIMS) for precise measurements on Isotope Dilution (ID) treated samples, and (2) Secondary Ionization Mass Spectrometry (SIMS). The ID-TIMS measurements were performed under different conditions and in different isotope laboratories. The Finnish Geological Survey determinations (by M.V.) were carried out during the late 1980-ties at an early stage of the investigation and employing relatively large samples of $>1000$ crystals each. The multi-grain technique described by Vaasjoki et al. (1991) was used. The more recent analyses from the Swedish Museum of Natural History (by T.S.) comprised just one or a few mineral grains according to a single-grain technique. The SIMS analyses were carried out on a Cameca 1270 ion probe which is a Nordic research facility (NORDSIM) at Stockholm. In regard to the various analytical procedures employed in Stockholm, we refer to Rutland et al. (2001b) and references therein. The errors and error calculations in the Tables and the text are given at the $95 \%$ confidence level, i.e. using 2-sigma uncertainties. 


\section{Results and interpretations}

\section{I. Samples and analytical data}

Our study involved detailed mapping and revision of some key areas in the Åland archipelago with emphasis on the large-scale structural pattern and its evolution. In isotope geology, we have used the most modern techniques to quantify the time dimension for these processes. By employing small-scale SIMS spot analyses from specific domains inside zircon grains, we enhanced the possibility of analysing homogenous parts in otherwise complex crystallizations. That technique is extremely useful for rocks with the potential of assimilating xenocrystic parts, and provides insight in regard to relic provenances as well as later metamorphic episodes. Because of such complexities, we screened/filtered our SIMS data to provide the detailed age information for the specific stage of zircon crystallisation that we aimed for. That procedure necessitated repeated analyses and statistical treatment of the data where the separate age determination often carried relatively large uncertainties. In comparison, the ID-TIMS analyses provided excellent analytical precision, but ran the risk of sampling diverse crystallizations.

The analytical data and age calculations are presented in Table 1 for 131 new SIMS and in Table 2 for 33 new ID-TIMS determinations. Histograms of age distributions as well as regressional and other statistical treatments involving these determinations are illustrated in a number of figures. Cathode luminescence (CL) and transmitted light (TL) photographs taken prior to analysis helped select characteristic grains and were used to guide the spot analyses. They record different crystal textures and morphologies relevant to the interpretation and discussion of the ages significant for specific episodes of crystallization.

The investigated rock samples represent a cross-section of ages from the repeatedly deformed granitoid gneisses of the Enklinge, Torsholma, and Kökar-Sottunga areas and forward in time to the gently deformed granitoid dykes associated with the very late stages of Svecofennian deformation.

Sample A1185 is from a c. one metre wide pegmatite dyke that cuts vertically across the deformed stack of rocks on the islet of Hummelholm, Torsholma (Fig. 2:4). The pegmatite is undeformed and obviously post-dates the collisional tectonic phase. Concordant monazites yield a $U-P b$ age of $1795 \pm 4 M a$ (not shown graphically).

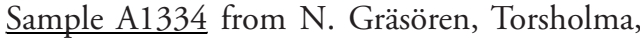
represents the allochthonous granulitic gneisses that have been thrusted eastwards between the country-rock gneisses. Their zircons are stubby, short-prismatic, and often light-brown and translucent with an internal zoning. Some grains contain turbid cores. The degrees of discordance between zircon populations increase with rising uranium contents and decreases in density. By excluding the most discordant and dark brown zircons (fraction E, Table 2, not shown graphically) a linear trend with an upper intercept age of $1867 \pm 15 \mathrm{Ma}$ and a lower one at $325 \mathrm{Ma}$ is defined. The high MSWD value of 10 indicates scatter in excess of analytical error. Yellow anhedral monazite is almost concordant with a ${ }^{207} \mathrm{~Pb} /{ }^{206} \mathrm{~Pb}$ age of $1829 \pm 5 \mathrm{Ma}$.

Sample A 1261, Räddarskär, Torsholma represents a generation of gneissic granitoids that overlie discordantly and cut across the granulitic gneisses. This subhorizontal sheet is free from cross-cutting amphibolite dykes and obviously represents an episode of intrusion into a previously formed collage of rocks. The most abundant zircons are prismatic, of medium length and with well-developed regular zoning. Some opaque inclusions have been excluded, leaving the low density and more turbid population quite discordant. A regression of all four populations results in a MSWD of 7.9 and Concordia intercept ages of $1861 \pm 19$ and $221 \mathrm{Ma}$ (not shown graphically). 
Sample A 1187 Bockholm, Torsholma is from a granodioritic dyke crosscutting the A1334 granulite which, based on field observations, belongs to the same phase of intrusion as the Räddarskär sheet (sample A1261). Under oil immersion, the zircons display zoning and multiply faceted crystal terminations. The five populations separate into two groups, and a linear trend with Concordia intercept ages of $1865 \pm 7$ and 338 Ma can be calculated (not shown graphically). The MSWD of 1.4 indicates little or no scatter in excess of analytical errors. The dyke contains rounded monazite grains with a ${ }^{207} \mathrm{~Pb} / 206 \mathrm{~Pb}$ age of $1827 \pm 4 \mathrm{Ma}$.

The zircon fractions from samples A1334, A1187 and A1261 were all subjected to multi-grain ID-TIMS analysis on large quantities of crystals and carried out in the later part of the 1980-ties. The relatively large MSWD-values and \pm errors are most likely the results of heterogeneous zircon crystallizations involving significantly different growth stages. This is probably also true of the numerous multi-grain analyses previously reported. The uncertainty problem is particularly severe in the case of analyses aimed at reflecting early stages of development, which may have been influenced by late-stage annealing, metamorphism and the presence of xenocrystic grains from older continental rocks.

Sample 98033 represents a granulitic gneiss at Lilla Hummelholm, Torsholma. It is from the same rock type as sample A1334. This granulitic gneiss carries abundant clino- and ortho-pyroxenes which cause the brownish appearance. The rock has been deformed at least twice before reaching its present state, and both TIMS and SIMS ages are available. The zircons are mainly short-prismatic and colourless transparent to translucent. Irregular and button-like yellow monazites occur.

The cathode-luminescence (CL) and transmitted light (TL) images shown in Fig. 4 illustrate the characteristics found among the zircons of this granulite sample (98033). Despite the metamorphic features, magmatic type zon- ing is still the dominant texture in the central parts of the zircon grains. There, the CL images are visible as irregular growth bands of variable greyish intensity. Marginal domains of homogeneous CL-dark reflection have been analysed in two instances (grains 02a and 04a) and yield ages of 1826 and $1828 \mathrm{Ma}$ (see Fig. 4 and Table 1). CL-greyish and zoned interiors, reflecting changes in element concentrations associated with magmatic crystallization, constitute 8 of the totally ten analyses. The weighted average mean of the ${ }^{207} \mathrm{~Pb} /{ }^{206} \mathrm{~Pb}$ ages for these eight $(\mathrm{n}=8 / 10)$ analyses (thus excluding analyses $02 \mathrm{a}$ and $04 \mathrm{a}$ ) is $1876 \pm 11 \mathrm{Ma}$. The MSWD value for this calculation is 3.8 and the age distribution is shown in the histogram of Fig. 4.

The analytical SIMS-results can also be expressed in the form of a Concordia plot (not shown). A best fit to a straight line of the eight older analyses yields intercept ages of $1885 \pm 14$ and c. $610 \mathrm{Ma}$. Since the lower intercept of 610 $\mathrm{Ma}$ is rather high for a lead diffusion curve and less likely to mark recent lead loss or a metamorphic event, a lower intercept anchored at 250 Ma would probably result in a more realistic upper intercept age of $1878.7 \pm 5.8 \mathrm{Ma}$ at the $95 \%$ confidence level and a MSWD of 1.3. Similarly to all the other calculations made for this publication, these ages have been calculated using a $95 \%$ confidence level or correspondingly given with 2-sigma uncertainties in Table 1.

We have also carried out some ID-TIMS single-grain analyses on selected short-prismatic anhedral zircons which, prior to isotope dilution (ID), were abraded (Krogh, 1982) to remove potential metamorphic overgrowths and heterogenities in the marginal, sometimes disturbed parts of the grains. Both these ID-TIMSanalyses (samples $98033 \mathrm{D}$ and $\mathrm{E}$ in Table 2) are somewhat discordant, yielding ${ }^{207} \mathrm{~Pb} /{ }^{206} \mathrm{~Pb}$ ages of c. $1869 \mathrm{Ma}$ (Fig. 4 centre). We have not identified any inherited/xenocrystic zircon core domains in this material, but any addition from metamorphic overgrowths would immediately render the ID-TIMS age determinations of 1869 Ma to become a minimum age of prima- 


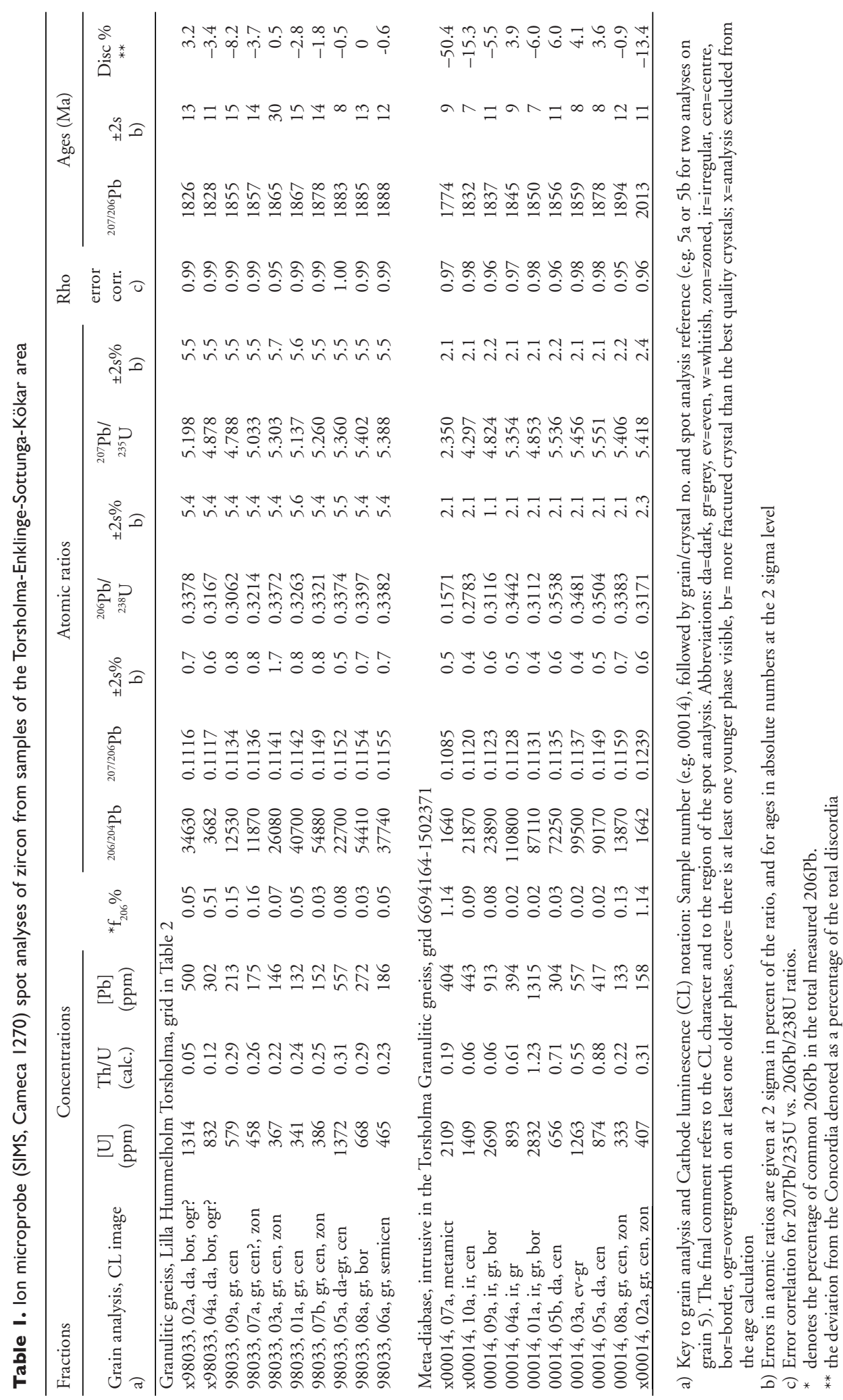




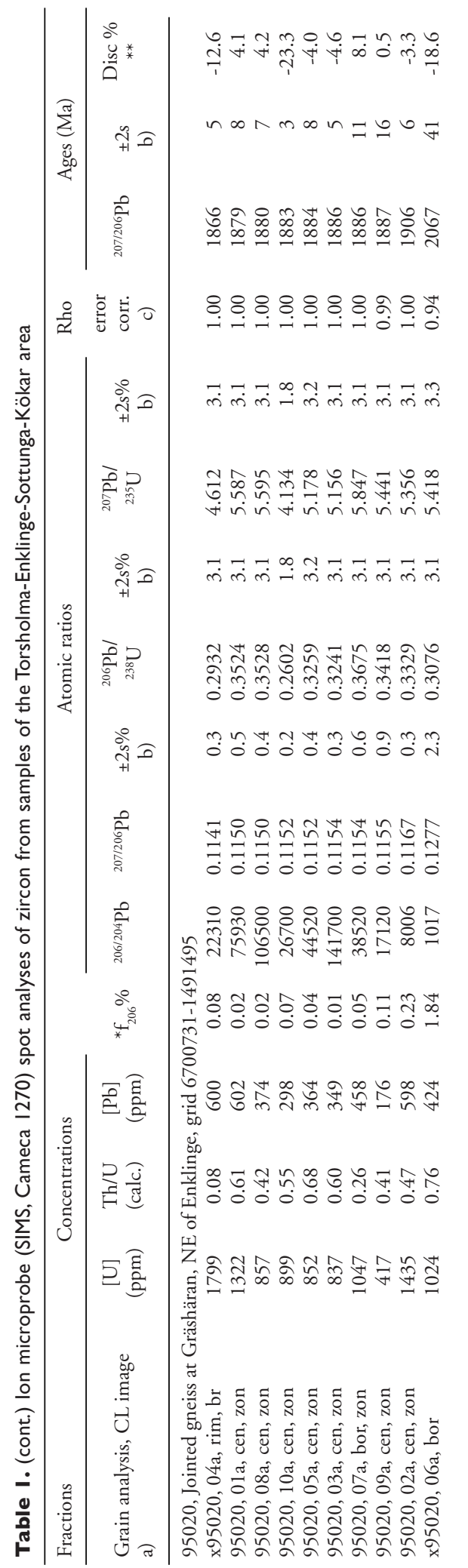

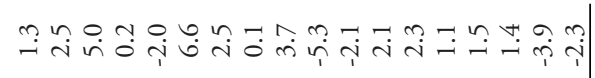

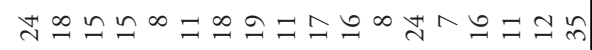

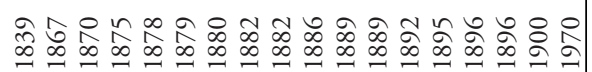

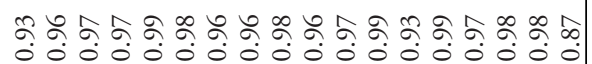

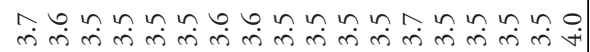

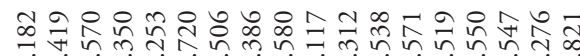

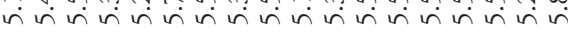

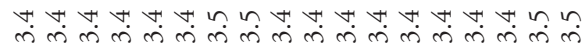

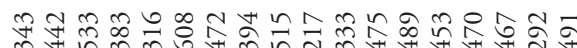

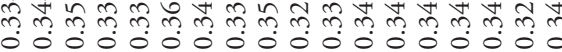
m

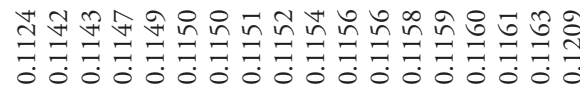

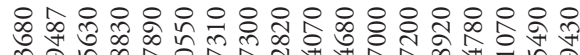

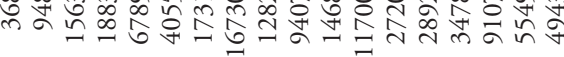

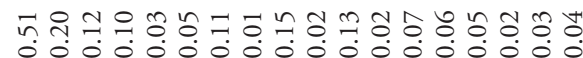
๘

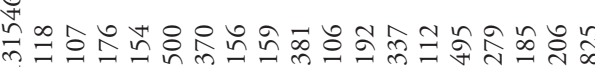
完

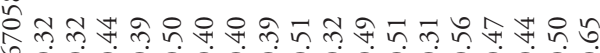
0.00000000000000 要

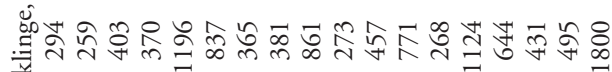

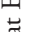

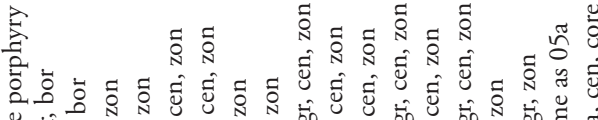

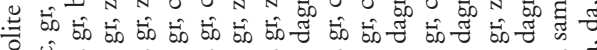

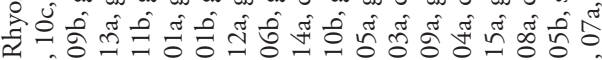
ले

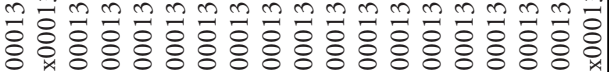




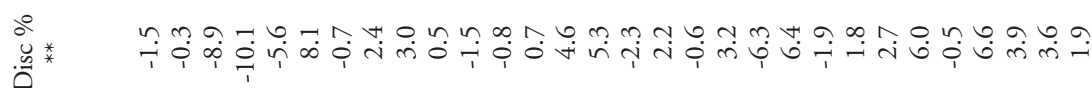

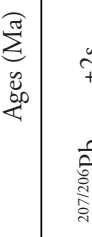

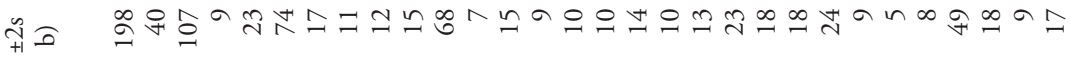

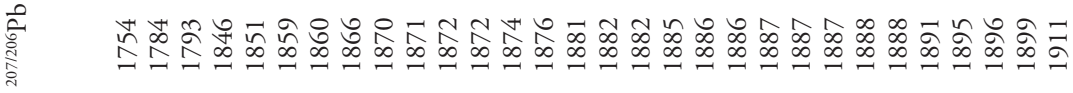

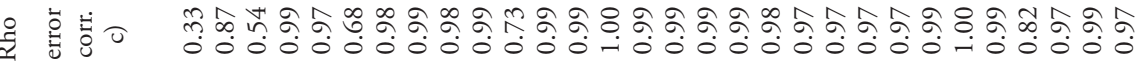

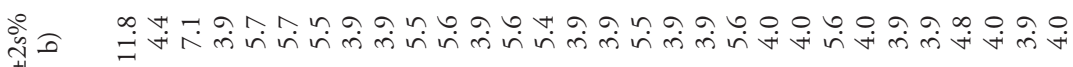

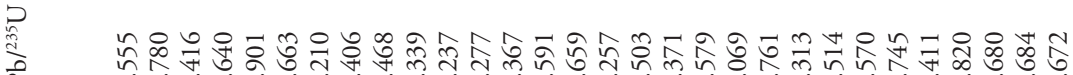

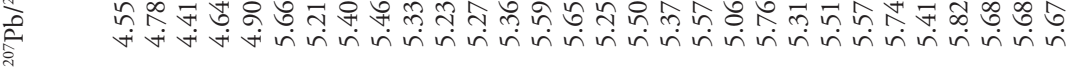

ஸें

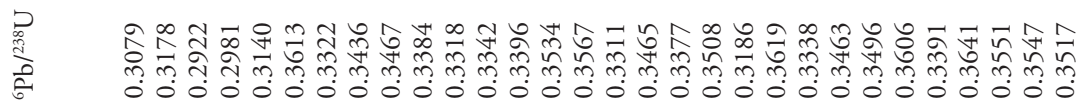

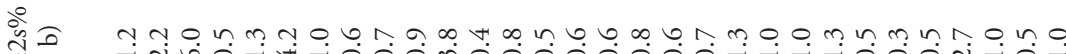

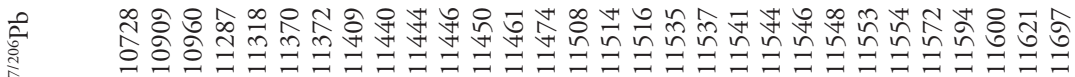

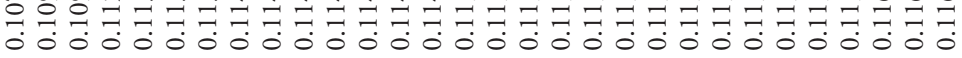

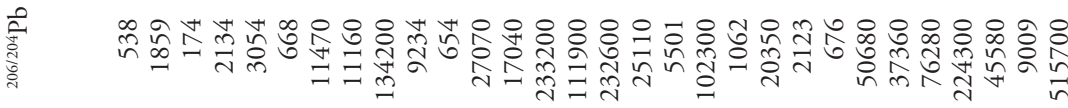

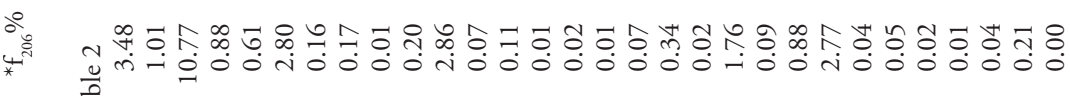
苛

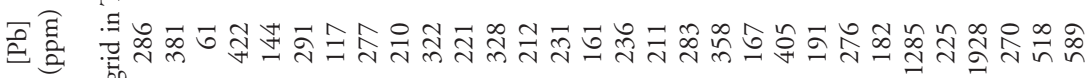
(⿸丆口

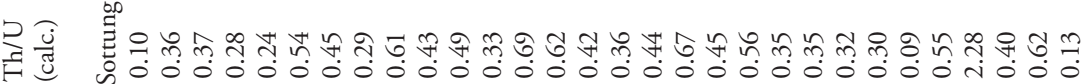

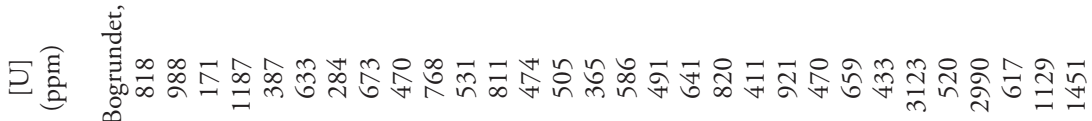

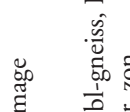

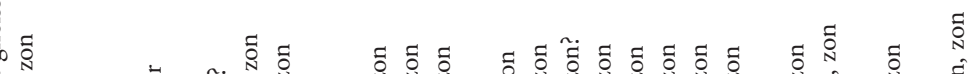

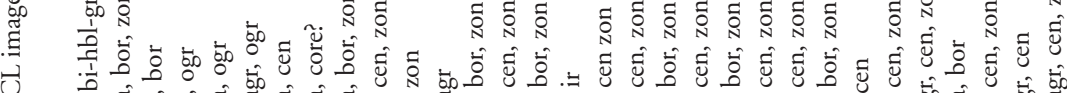

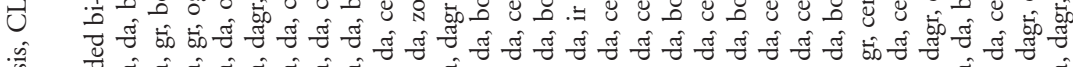

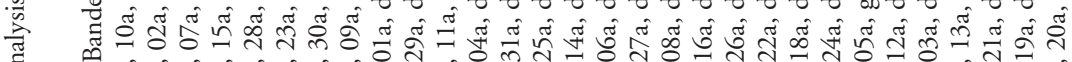

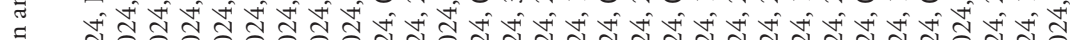

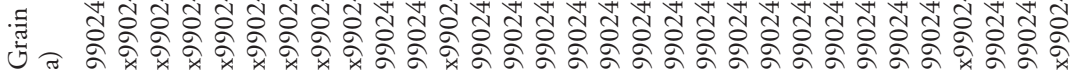




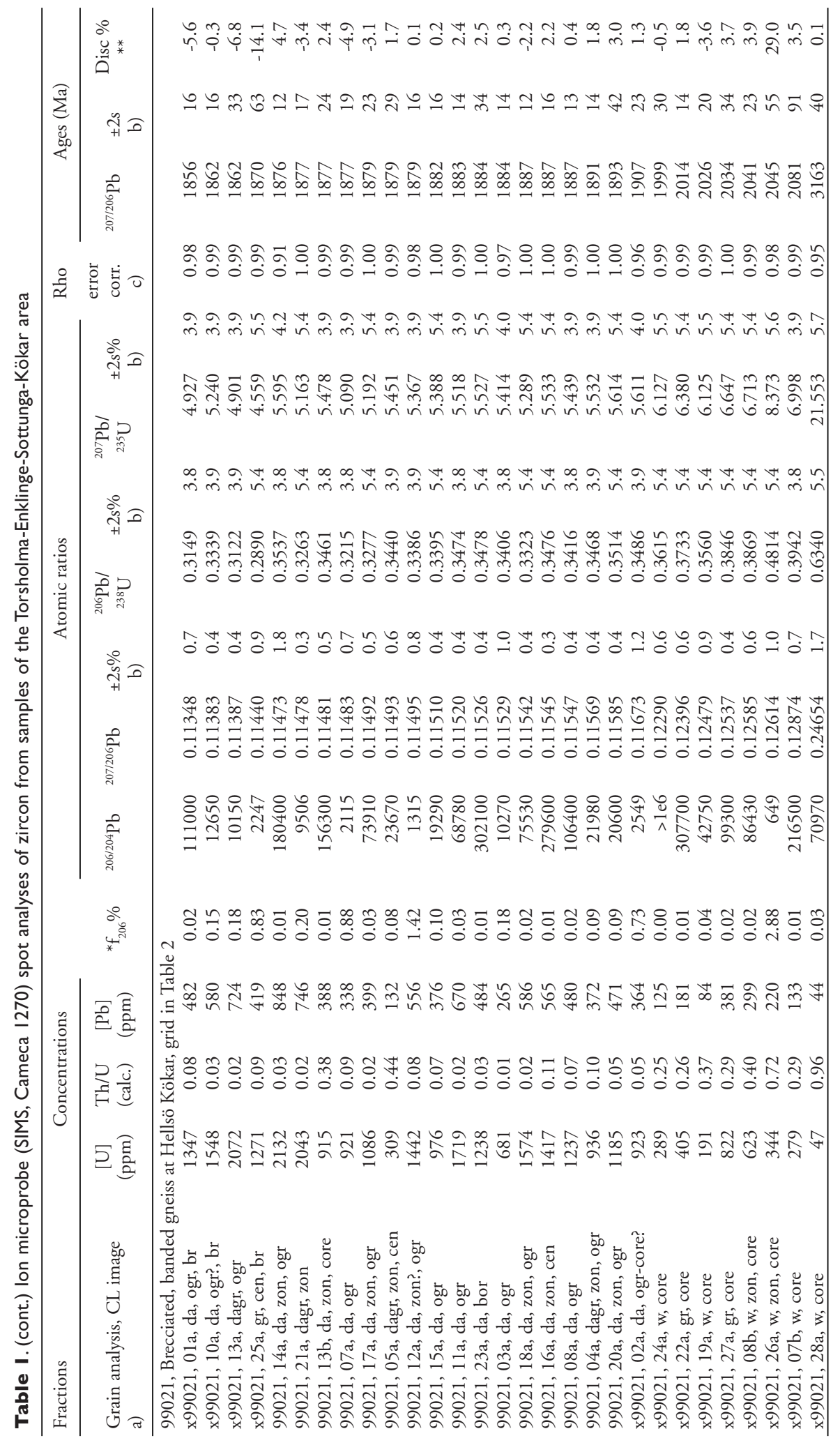




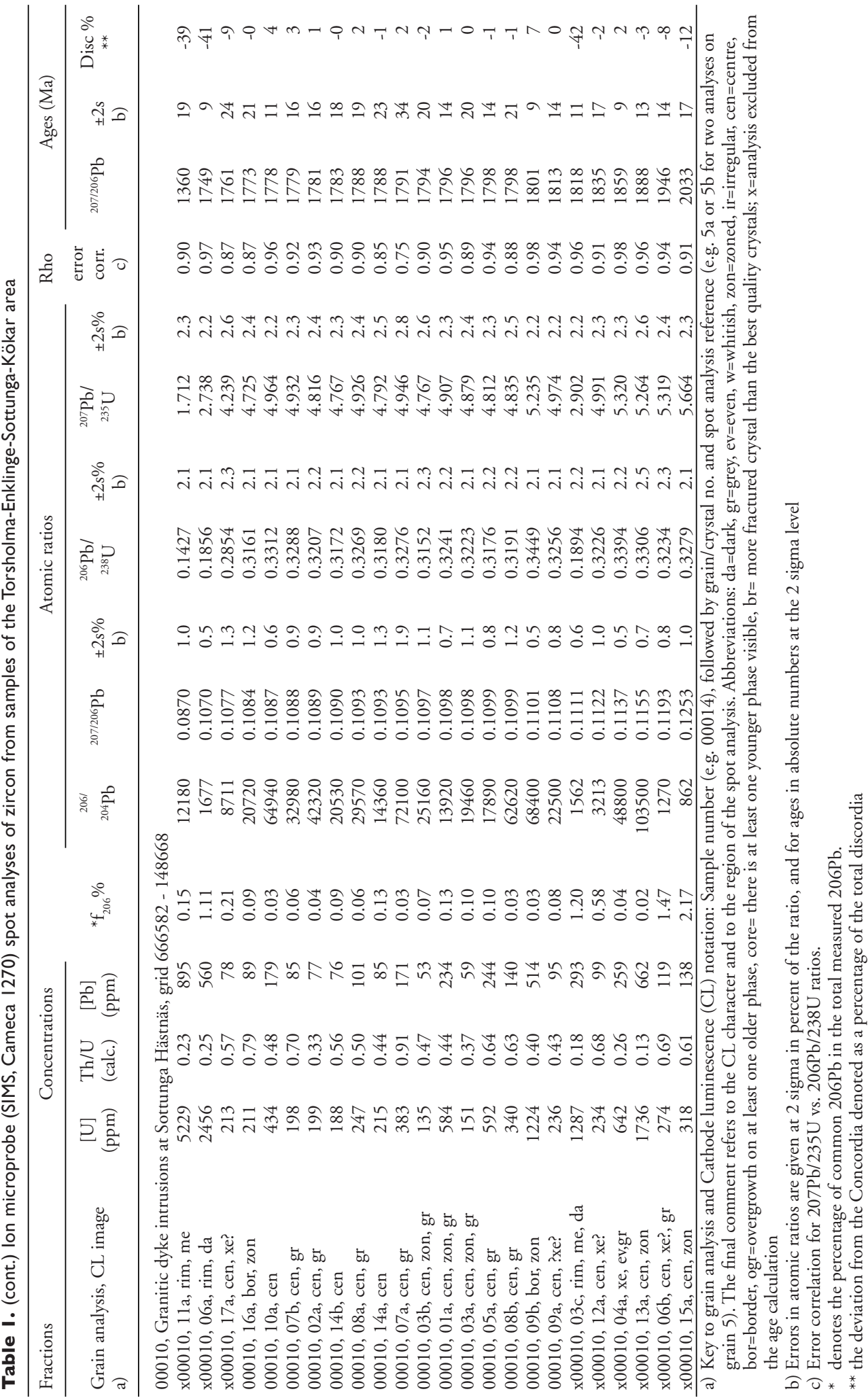



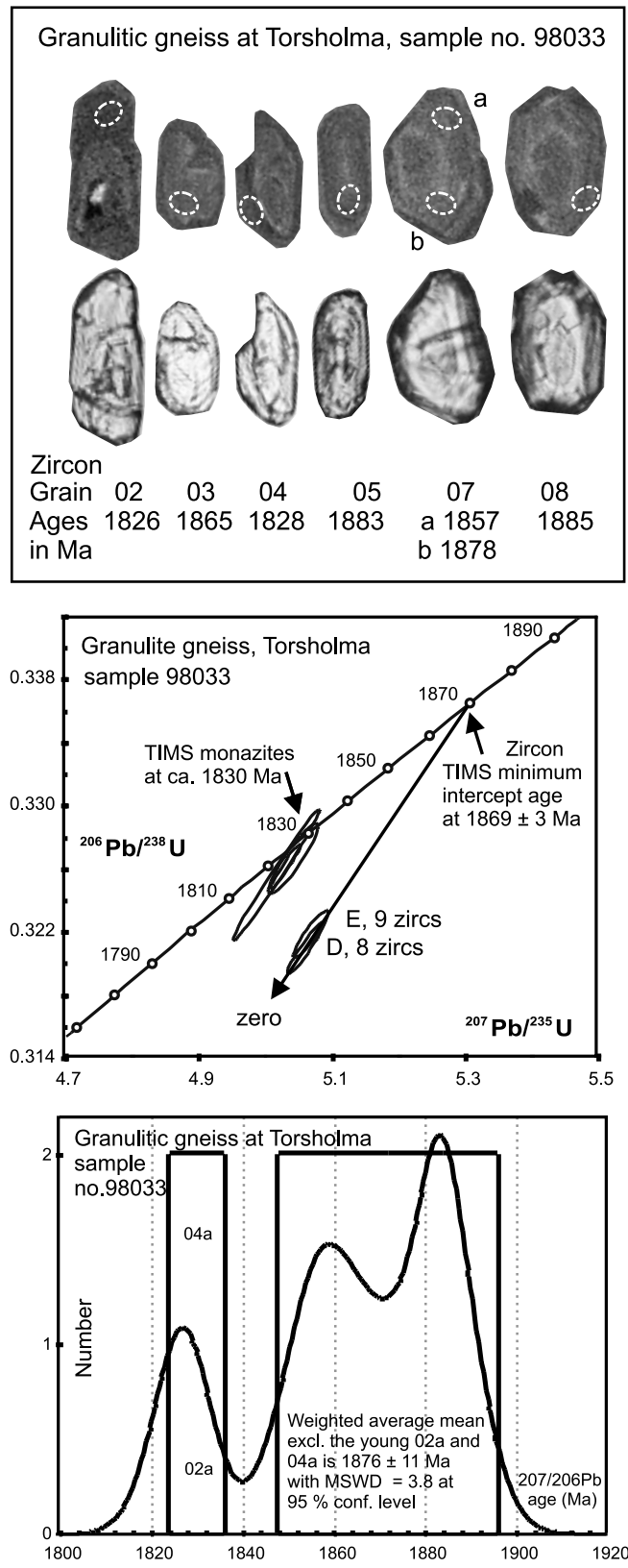

ry crystallization. Therefore we consider the previously calculated "anchored SIMS concordia" of $1879 \pm 6 \mathrm{Ma}$ (Fig 2:1) to best define the time of primary zircon crystallization, which also is the best approximation for the time of magmatic emplacement.
Fig. 4. Granulitic gneiss at Torsholma (sample 98033). Upper part: cathode luminescence $(\mathrm{CL})$ and transmitted light (TL) images of six selected grains are shown with the detailed locations of SIMS spot analyses. Metamorphic and texturally homogeneous overgrowth domains yield ages of about I830 Ma. Central part: these zircon overgrowth ages compare well with ID-TIMS metamorphic monazite ages. Also shown are discordant microgram analyses which most likely represent a minimum age of original zircon crystallization. Bottom part: histogram of SIMS spot analyses yields a mean ${ }^{207} \mathrm{~Pb} /{ }^{206} \mathrm{~Pb}$ age of I876 I I Ma for euhedrally zoned domains.

The two youngest SIMS analyses from the overgrowth domains of zircon grains $02 \mathrm{a}$ and 04a (1826 and $1828 \mathrm{Ma}$, and displayed in the CL and TL images of Fig. 4) are very similar to the concordant ID-TIMS single-grain monazite ages of 1828, 1831 and $1829 \mathrm{Ma}$ (Table 2, sample 98033 A, B, C and Fig. 4 centre). Together these ages indicate significant medium- to highgrade metamorphic recrystallization in the Torsholma area very close to $1830 \mathrm{Ma}$. Because of different blocking temperatures for zircons and monazites, the similarity in the metamorphic ages obtained also suggests that the cooling/ uplift was a relatively rapid process.

Sample 99021 is from the island of Hellsö, Kökar. It represents the quartz- and feldspar-rich neosome associated with a brecciated pod of mafic gneiss. The surrounding rocks are bands of mafic boudins within a strongly deformed granodioritic-dioritic gneiss sequence. Zircon is abundant and mostly occurs as brownish short-prismatic grains. Occasionally, secondary overgrowths create complex crystallizations in oval to rounded grains (Fig. 5). However, our expectations to find metamorphic zircon among the quartz-feldspatic recrystallization products proved negative. Three short-prismatic light brown (sample $99021 \mathrm{C}$ ) and ten long-prismatic zircon crystals (sample 99021 D) were investigated using the ID-TIMS technique. They yielded, within the limits of error, a combined age of $1889 \pm 3 \mathrm{Ma}$. This result is indistinguishable from that on the zircons from a nearby granodioritic gneiss sample at Kökar. 
Fig. 5. Brecciated gneiss at Kökar (sample 99021). Upper part: selected images of CL-light (cores) and CL-darker oscilatory zoned zircon domains with $\mathrm{Pb} / \mathrm{Pb} \mathrm{SIMS}$ spot ages. Central part: SIMS ages separated into two different age groups. Bottom part: a weighted average of sixteen out of a total thirty spot analyses indicates magmatic crystallization at $1884 \pm 3 \mathrm{Ma}$, while detrital cores fall into the 2080-2000 Ma age interval.

Seven zircon grains from sample 99022 A (see Table 2 fraction A) together mark an age of about $1891 \mathrm{Ma}$.

The SIMS investigation of sample 99021 showed some remarkable results: Thus there are no evidences of metamorphic zircon overgrowths from events younger than $1860 \mathrm{Ma}$. However, metamorphic titanite with ages of $\mathrm{c}$. $1784 \mathrm{Ma}$ (Table 2) indicates less pronounced recrystallization as a result of shearing of the two Kökar gneisses. The kinds of zircon crystallization that are most evident in this sample, constitute zoned magmatic crystallizations which surround cores that are well distinguished in CL images (cf. zircon grain 26 and 28 in Fig. $5)$. Eight such core portions have been analysed. Out of these, as many as seven cores yield$e d^{207} \mathrm{~Pb}{ }^{206} \mathrm{~Pb}$ ages within the time interval 2000 $2080 \mathrm{Ma}$, (cf. the histogram in Fig. 5), while the oldest core is $3163 \mathrm{Ma}$ old. Obviously, this rock sample indicates the presence, not only of minor Archaean material, but also of significant amounts of continental crust formed just before $2000 \mathrm{Ma}$.

The other SIMS spot analyses were directed to parts of zircon crystals where some kind of zoning reaching the grain edges is present. The four youngest of these ages are considered to be the result of grain and/or instrument disturbances, and spot 02a may well cover several heterogeneous domains. The remaining sixteen analyses define a discordia which intercepts the concordia at $1882.6 \pm 3.7 \mathrm{Ma}$ and $358 \mathrm{Ma}$, with a MSWD of 0.66 at the $95 \%$ confidence level. The weighted average ${ }^{207} \mathrm{~Pb} /{ }^{206} \mathrm{~Pb}$ age for these sixteen analyses is $1884 \pm 3 \mathrm{Ma}$ (Fig. 5 centre).

The ID-TIMS ages (Table 2) are precise but significantly older and, above all, scattered be-
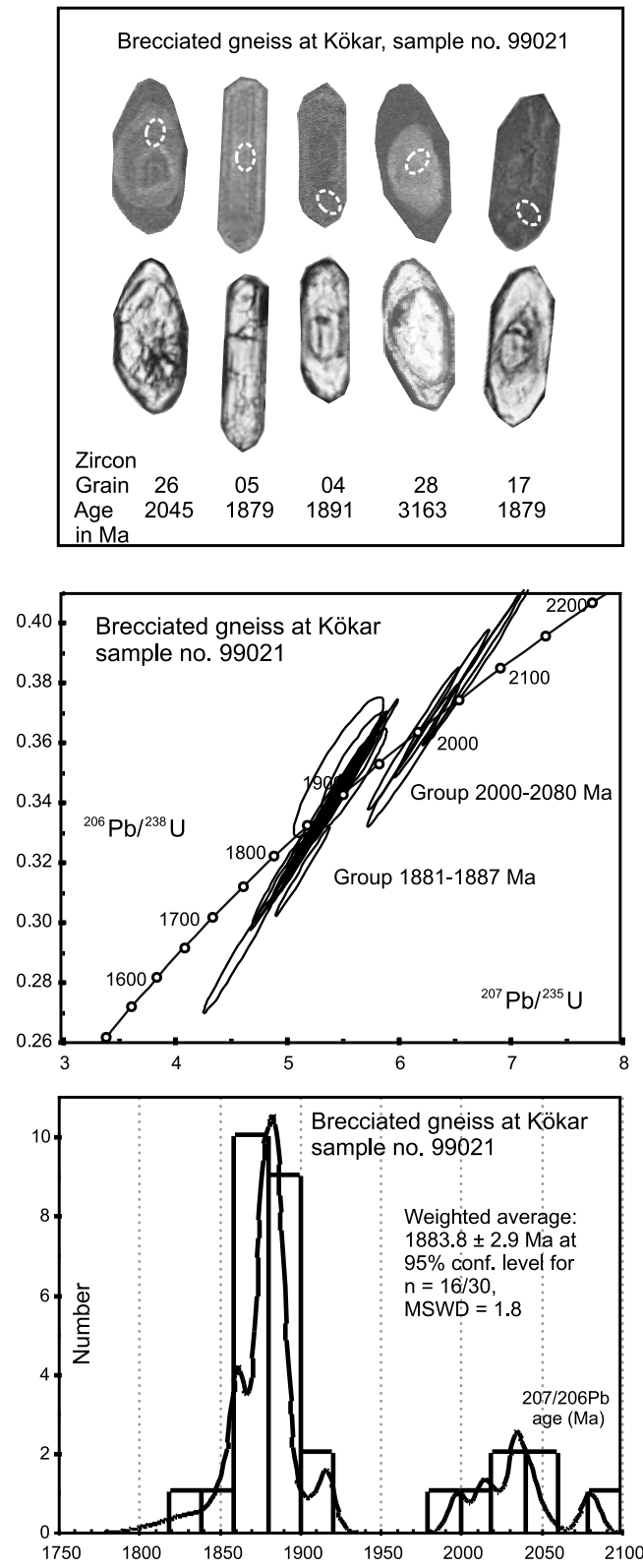

yond the individual uncertainties encompasing whole grains. At least fraction $99021 \mathrm{~B}$ most likely contains core materials not seen under the microscope. Therefore, these TIMS ages are considered blended/mixed ages. This leaves the SIMS based age of $1884 \pm 3 \mathrm{Ma}$ as the best approximation for the time of magmatic rock emplacement. 
Table 2. U-Pb TIMS-ID analytical data on zircon and monazite from the Torsholma - Enklinge and Kökar - Sottunga areas

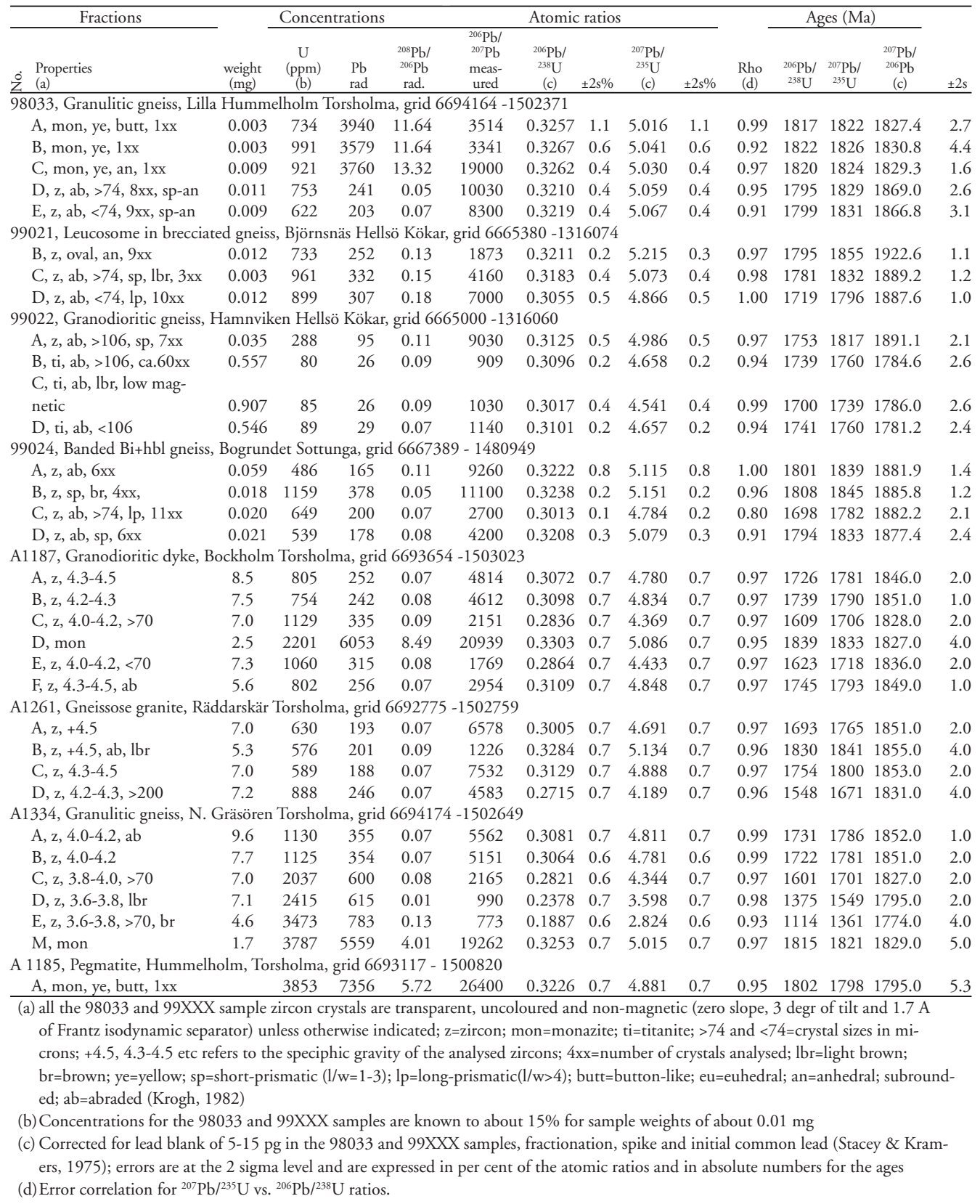

Sample 99022 is a granodioritic gneiss with blastomegacrystic feldspar that was sampled on Hellsö, Kökar. The zircons are often colourless and free from cracks, and display a range of long-prismatic to round morphologies. Only one ID-TIMS zircon analysis was carried out on abraded grains of this rock sample. The mean ${ }^{207} \mathrm{~Pb} /{ }^{206} \mathrm{~Pb}$ age of a small number of crystals is $1891 \pm 2 \mathrm{Ma}$ (Table 2, not shown graphically). Since there is a clear possibility that this analysis 
Fig. 6. Banded biotite-hornblende-gneiss at Sottunga (sample 99024). Upper part: CL and TL images from five representatives of zircon grains with their locations and corresponding SIMS $\mathrm{Pb} / \mathrm{Pb}$ age figures. Bottom part: plotting of SIMS spot analyses in a Concordia diagram where nineteen spots are considered to approximate the crystallization age of the rock. Taking the SIMS weighted average and the ID-TIMS data into consideration, an age of $1884 \pm 5 \mathrm{Ma}$ is suggested.

include at least some inherited radiogenic lead, the obtained age must be considered a maximum age of rock crystallization.

Three populations of titanite crystals were also investigated radiometrically from this rock. They yield somewhat discordant results with ${ }^{207} \mathrm{Pbl}$ ${ }^{206} \mathrm{~Pb}$ ages of 1786,1785 and $1781 \mathrm{Ma}$ (not shown graphically).

Sample 99024 is from a banded biotite-hornblende orthogneiss on the island of Sottunga. The rock has been strongly deformed by ductile shearing, occasionally showing strong sheath folding. There is a range of zircon morphologies that may comprise both xenocrystic and metamorphic parts. The rock was sampled close to a younger granitic dyke intrusion (comparable to the rock type sampled as 00010 described below) which registers significantly later deformations within the shear zone. The thirty SIMS spot analyses performed were mainly directed at domains of zoning and where CL-images are homogeneously dark or show an interplay of darker and lighter lamellae. By excluding analyses with large instrumental uncertainties, discordancies and/or clearly separate ages (the ones excluded from the regression are indicated by an $\mathrm{x}$ before their numbers in Table 1 and by their spot numbers in Fig. 6), we end up with a group of nineteen that yield concordia-discordia intercept ages at $1882.3 \pm 4.7 \mathrm{Ma}$ and $158 \mathrm{Ma}$. The corresponding weighted average ${ }^{207} \mathrm{~Pb} /{ }^{206} \mathrm{~Pb}$ mean age is $1884.1 \pm 3.8 \mathrm{Ma}$ with a MSWD of 2.4 . The very young ages, like those of spots 02 a (Fig 6), 15a and 28a which show influences of younger events, were excluded and may have been related to the emplacement of the adjacent intrusive granites.
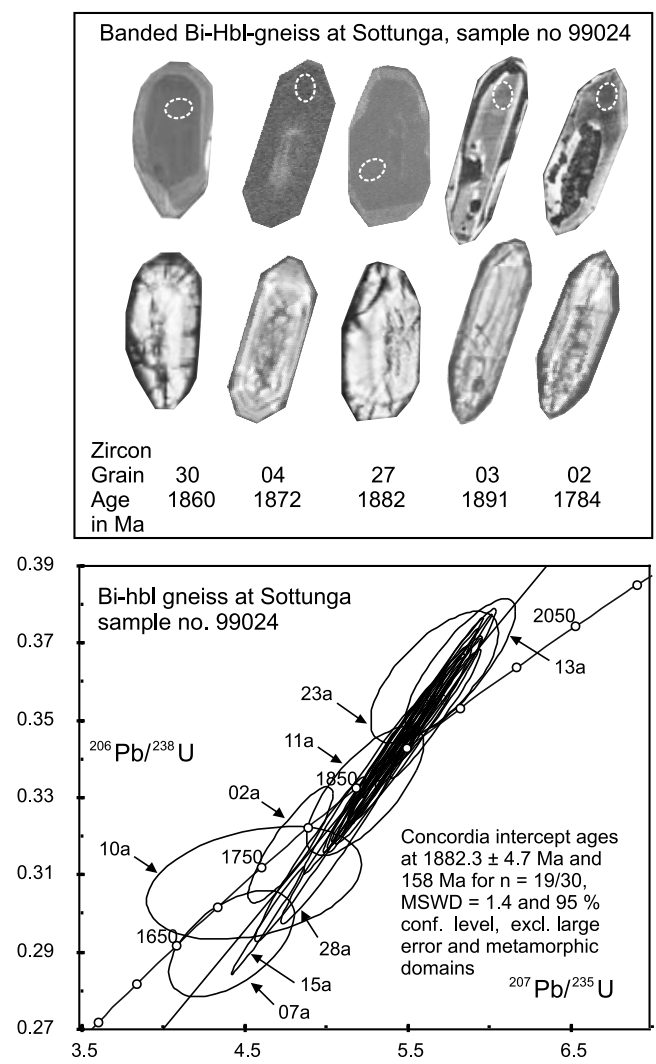

The ID-TIMS analyses of four zircon populations with varying morphologies and colouring yield ${ }^{207} \mathrm{~Pb} /{ }^{206} \mathrm{~Pb}$ ages between 1886 and 1877 Ma. Although the grains were abraded before chemical dissolution, there is some suspicion of metamorphic additions in the young age. Xenocrystic cores with CL-white images occur in some of the mounted grains (compare CL image of spot 04 in Fig. 6), but none of these have been analysed from this sample and their ages are therefore unknown. The IDTIMS ages of the three older populations vary from 1882 to $1886 \mathrm{Ma}$ and are within the uncertainties of the mean SIMS ${ }^{207} \mathrm{~Pb} /{ }^{206} \mathrm{~Pb}$ age. From a consideration of the various age data, we suggest an age of $1884 \pm 5 \mathrm{Ma}$ as the best approximation for the crystallization of the magmatic zircons and the emplacement of this rock. 

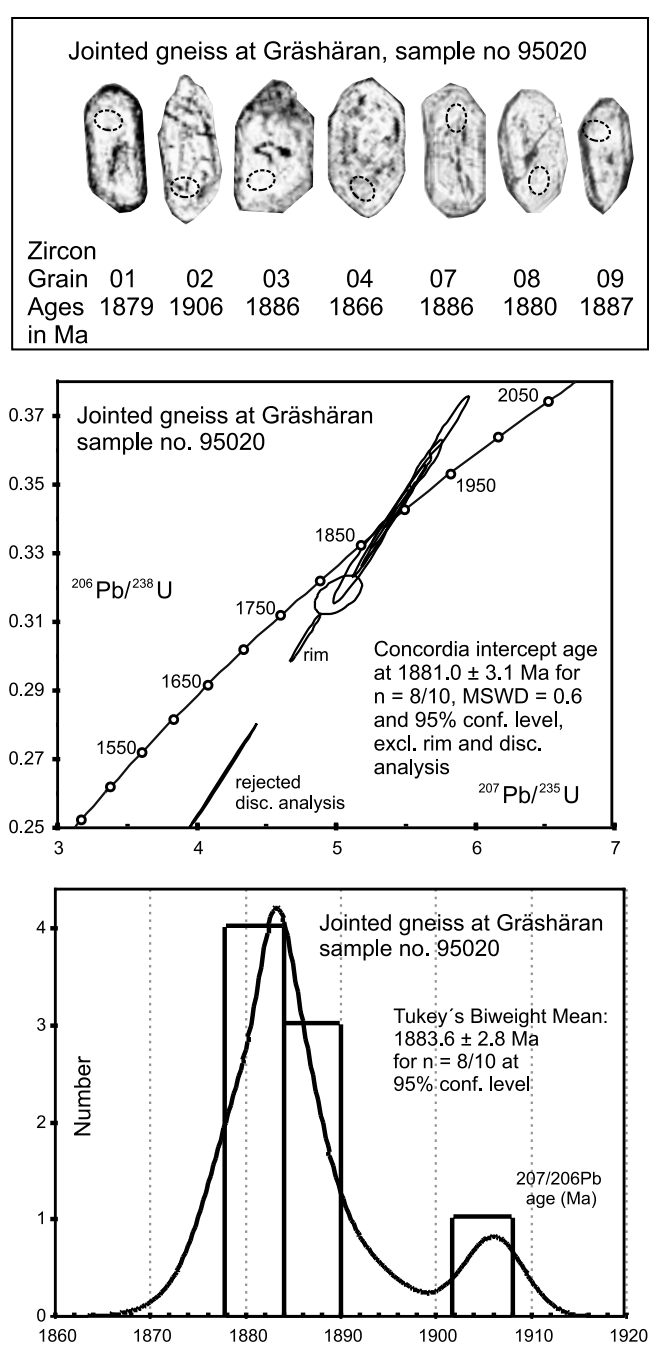

Sample 95020 represents a grey, strongly deformed tonalitic-granodioritic gneiss with an axial- plane schistosity trending N40 E. The sample was collected at the islet of Gräshäran a few kilometres north of the island of Enklinge (Fig. 1). The zircon grains are generally shortprismatic with curved morphologies (high order hkl-indices) in the grain terminations. When immersed in alcohol or mounted in plastic and polished to expose internal textures, the zircons display marginal rims. Generally, these are richer in uranium and more turbid probably due to the development of micro-fractures. From the
Fig. 7. Jointed gneiss at Gräshäran (sample 95020). Upper part: transmitted light $(\mathrm{TL})$ images (texturally less distinct $\mathrm{CL}$ images are not shown) of zircon grains with spot locations and corresponding $\mathrm{Pb} / \mathrm{Pb}$ age figures. Central part plots of spot analyses resulting in a Concordia interintercept age based on all but two rejected rim and discordant analyses. Bottom part: histogram of SIMS spot analyses indicating a mean $\mathrm{Pb} / \mathrm{Pb}$ age of $1884 \pm 3 \mathrm{Ma}$.

point of ages and textures, eight out of the ten spot analyses $(n=8 / 10)$ make up a homogeneous group. Most of these are shown in transmitted-light (TL) photographs in Fig. 7. They yield a mean ${ }^{207} \mathrm{~Pb} /{ }^{206} \mathrm{~Pb}$ age of $1886.0 \pm 6.8 \mathrm{Ma}$ with a MSWD of 7.6. The rather high MSWD value is largely due to the presence of one (spot 02) disparate age, older than the majority of ages obtained (Fig. 7). By using Tukey's biweight mean calculation (Ludwig, 1991) instead of the weighted average mean, the distorted distribution is accounted for. The result is a lower, and probably more reliable mean age of $1883.6 \pm 2.8$ Ma at the $95 \%$ confidence level, approximated to $1884 \pm 3 \mathrm{Ma}$.

The contacts between the central domains and the metamorphic overgrowths are always sharp and follow closely the magmatic zonation of the zircons. Thus there are no signs of crystal absorption of the central parts that would result in indented boundaries crossing over the zonation and formed during the metamorphic overgrowth. Similarly, there are no traces of any erosional processes that could have worked/ abraded the zircon grains. Genetically, these features confirm a magmatic origin for the rock. The homogeneity of the zircon ages can sometimes be taken to indicate a single source. However, there is one rather old age of $2061 \mathrm{Ma}$, which has been excluded from the calculation. This age may well be a reflection of the presence of newly formed continental crust at about that time. Zircon ages of about $2000 \mathrm{Ma}$ and more are frequent in the Svecofennian sedimentary rocks distant from the Archaean craton (Claesson et al., 1993; Lahtinen et al., 2002). Furthermore, they make up a significant part of the zir- 
Fig. 8. Rhyolite at Enklinge (sample 000I3). Upper part: $\mathrm{CL}$ and $\mathrm{TL}$ images with the location of some zircon spot analyses and corresponding $\mathrm{Pb} / \mathrm{Pb}$ age figures. Central part: Concordia diagram forming a cluster of SIMS spot determinations. Bottom part: histogram of SIMS spot analyses indicating an average $\mathrm{Pb} / \mathrm{Pb}$ age of $1887 \pm 5 \mathrm{Ma}$. Considering all the different modes of calculation, the zircon crystalization indicates rock-forming processes at $1885 \pm 6 \mathrm{Ma}$.

con population in the Kökar sample (cores in sample 99021; Table 1).

Sample 00013 is from the island of Enklinge. It represents a rhyolitic porphyry with varying concentrations of fragments. According to the stratigraphic section suggested for the Enklinge area by Ehlers and Lindroos (1990b) that rock was deposited atop of the supracrustal pile of mainly mafic volcanic rocks. The homogeneously deformed rocks show a steep linear structure (rodding) with an almost circular $\mathrm{XY}$ section of the strain ellipsoid. There are outcrops with well preserved and only weakly distorted primary volcanic structures. The zircon crystals of this porphyry sometimes have radial and interlamellar cracks transecting simple prisms which are often terminated by distorted pyramids (Fig. 8). The CL-images show grey to darker grey domains that follow the internal lamellar textures. In some cases, thin metamorphic rims can be traced, but this is too minor a phenomenon to be analysed. The SIMS spot analyses (i.e. crystals 01,03 and 05 in Fig. 8) have been directed to what were considered to be homogeneous CL-domains which seemingly match undisturbed domains of lamellar growth zoning seen in the comparable transmitted light (TL) images.

With the exception of two analyses, one from a probable xenocrystic core $(07 a$, Table 1$)$ and the other from the marginal part of a grain (10c, from which we have two additional analyses of the central domains $10 \mathrm{a}$ and $10 \mathrm{~b}$ ), the remaining sixteen out of the eighteen $(n=16 / 18)$ analyses yield a discordia that intersects the concordia at $1888 \pm 7.5 \mathrm{Ma}(95 \%$ confidence lev-
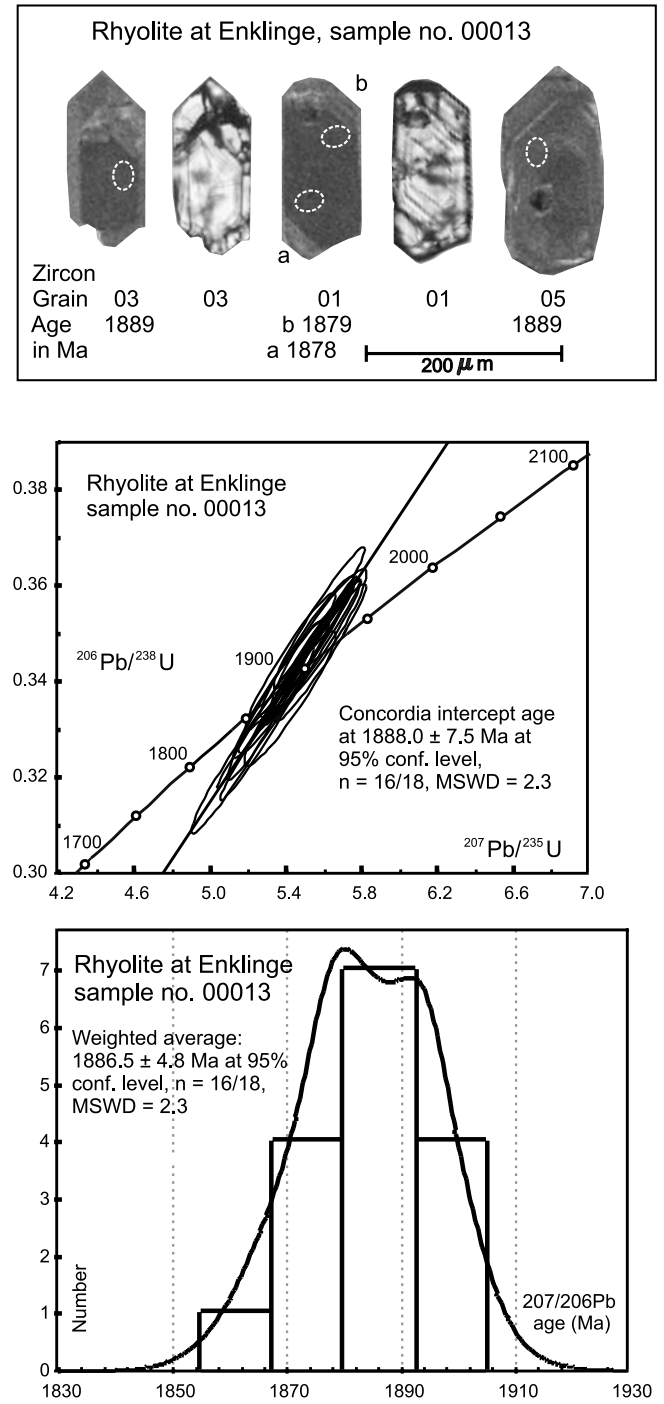

el and MSWD of 2.3). The weighted average of the ${ }^{207} \mathrm{~Pb} /{ }^{206} \mathrm{~Pb}$ ages is $1886.5 \pm 4.8 \mathrm{Ma}$, which should be compared to the age of Tukey's biweigthed mean of $1884.8 \pm 5.4 \mathrm{Ma}$. The situation where most analyses are concordant to almost concordant with no significant lead loss supports a calculation based on the ${ }^{207} \mathrm{~Pb} /{ }^{206} \mathrm{~Pb}$ ages. Thus, an age of $1885 \pm 6 \mathrm{Ma}$ is considered the best approximation for the formation of the Enklinge felsic porphyry. 

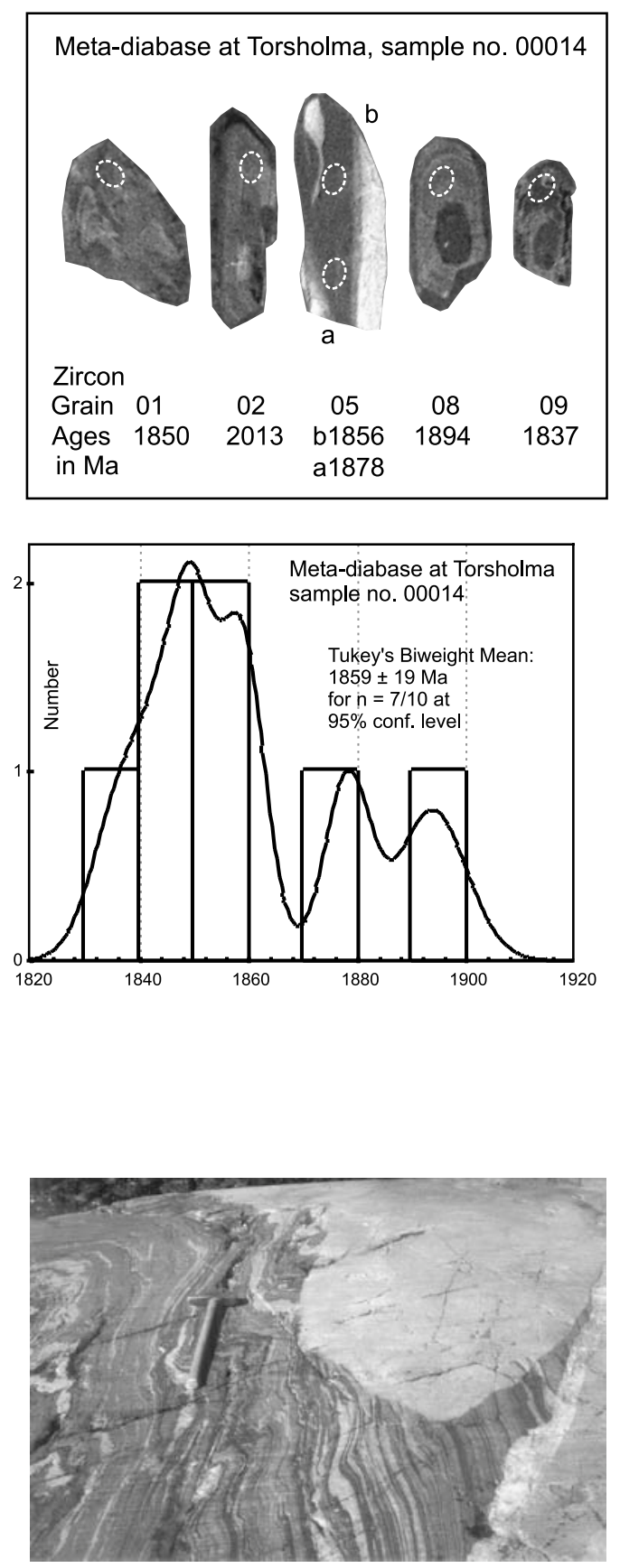

Fig. 10. Strongly deformed dioritic/granodioritic gneisses (SIMS U-Pb zircon age $1884 \pm 5 \mathrm{Ma}$ ) with amphibolitic bands are discordantly transected by a medium to fine-grained dyke of microcline granite with a SIMS $\mathrm{U}-\mathrm{Pb}$ zircon age of $1790 \pm 6 \mathrm{Ma})$. The locality is in the middle of the SFSZ on the western shore of the island of Sottunga.
Fig. 9. Metadiabase at Torsholma (sample 00014). Upper part: CL images from representatives of the few zircon grains available with their spot locations and corresponding $\mathrm{Pb} / \mathrm{Pb}$ age figures. Bottom part: histogram of the limited number of age determinations resulting in a less precise and rather hypothetical age of $1859 \pm 19 \mathrm{Ma}$.

Sample no 00014 is from a meta-diabase intersecting the granulite gneiss at Torsholma (Fig. $3)$. The zircons in this rock are few and only ten SIMS analyses were performed. Unfortunately these resulted in a span of crystallization ages indicating the probable presence of heterogeneous grains. Obvious outliers from what might be a main population are the very discordant and metamict spot nominated 07a (see Table 1) and analysis $02 \mathrm{a}$ from the central domain of a CLheterogeneous grain (Fig. 9). Analyses 05a and 05b seemingly sample similar portions of grain number 05 (Fig. 9), and the diverging age numbers (1856 and $1878 \mathrm{Ma}$ ) examplify the limited precision of single SIMS ages as compared with the ages of ID-TIMS. Therefore, weighted mean of SIMS ages or SIMS discordias should be based on a number of spot analyses sufficient to allow statistical treatment. If also analysis $10 \mathrm{a}$ is rejected (because of the known effect of an $1830 \mathrm{Ma}$ event in the country gneisses, but also for the relatively high negative discordancy), we may calculate a mean ${ }^{206} \mathrm{~Pb} /{ }^{207} \mathrm{~Pb}$ age for the remaining seven analyses of $1859 \pm 19 \mathrm{Ma}$. These seven analyses span an age interval of 1837 to $1894 \mathrm{Ma}$. At the moment there are no reliable criteria to exclude some of the younger ages apart from the noted influence of metamorphism at about 1830 Ma. Having this in mind, however, an age in the older part of the $1859 \pm 19$ $\mathrm{Ma}$ interval seems to be the more likely one to match the time of magmatic zircon crystallization and dyke intrusion.

Sample no 00010 is from a granite dyke at the Hästnäs locality on Sottunga island, situated in the prominent ductile SFSZ shear zone. The dyke is $5-10$ metres wide and cuts the folded and banded gneisses (Fig. 10). Despite the fresh 

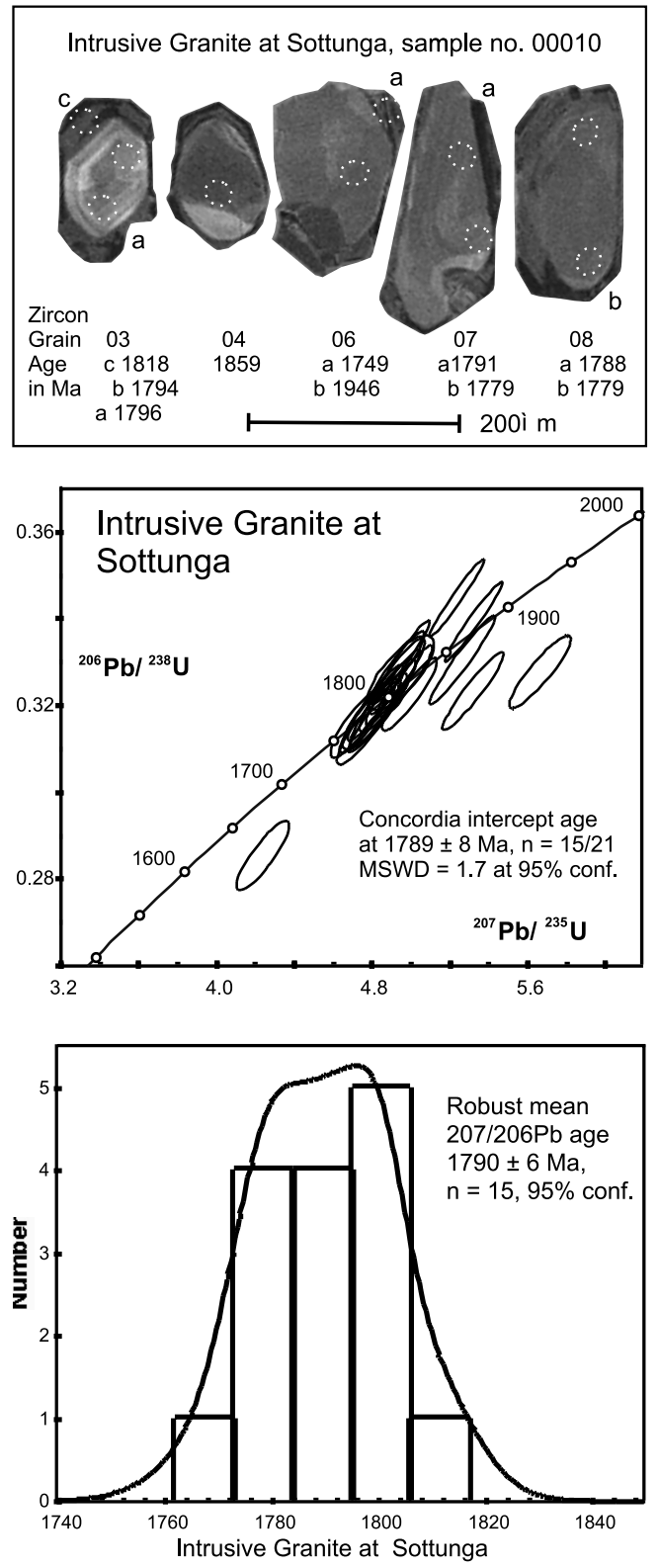

nature of the rock, its zircon grains show complicated crystallization patterns. In some instances, possibly xenocrystic cores make up the central parts of the grains (spot 04 in Fig.11), while metamict and uranium-rich zircon constitutes the outer rims (e.g., spot 07). These late crystallizations are readily seen as CL-dark images against the often zoned CL-greyish-white
Fig. I I. Intrusive granite at Sottunga (sample 000I0). Upper part: $\mathrm{CL}$-images of selected zircon grains showing the $\mathrm{Pb} / \mathrm{Pb}$ age figures for the spot determinations indicated. Central part: Concordia plotting of all but the most discordant analyses. Bottom part: histogram indicating a mean $\mathrm{Pb} / \mathrm{Pb}$ age of the more coherent determinations leading of $1790 \pm 6 \mathrm{Ma}$.

(e.g., grain 03 in Fig. 11) and sometimes irregular central domains. The metamict characters of the three uranium-rich rims that were analysed prohibit age calculation for these late additions. On the other hand, the freshness of the sampled dykes as well as signs of absorption to similarly aged central domains of the zircon grains (cf. grains 03 and 07 in Fig. 11) argue against a metamorphic event significantly separate from the time of intrusion. We prefer a scenario involving the crystallization of rims to create the euhedral outer zircon morphologies (cf. the different phases of grain 03 shown in Fig. 11) during a stage linked to the original rock crystallization. In accordance with an evolving magma chamber, the chemistry of the crystallizing agents had developed into more uranium-rich concentrations.

Twentyfour SIMS spot analyses on various zircon domains from sample 00010 have been performed. Out of these analyses, the spots of relatively young ${ }^{207} \mathrm{~Pb} /{ }^{206} \mathrm{~Pb}$ ages $(11 \mathrm{a}, 06 \mathrm{a}$ and 17a in Table 1) have been excluded due to a combination of being discordant uranium-rich rims, having poor accuracies, and relatively low ${ }^{206} \mathrm{~Pb} /{ }^{204} \mathrm{~Pb}$ ratios from the influences of common lead. Six analyses in the older range of ${ }^{207} \mathrm{~Pb} /{ }^{206} \mathrm{~Pb}$ ages have likewise been put aside because of (1) poor precision and being relatively older than their interior parts (cf. spot analysis $03 \mathrm{c}$ in relation to $03 \mathrm{a}$ and $\mathrm{b}$ also visualized in Fig. 11); (2) occupying central grain domains of somewhat roundish morphology with potential xenocrystic origin (cf. grains 04 and 12a in Fig. 11); and (3) exhibiting too old and disparate age figures in order to have a cause of crystallization common to the majority of spot analyses. Among these, we again note the presence of plus-2000 Ma, most probably continental 
zircons in the area (e.g., 00010 and 15a in Table 1). The remaining fifteen spot analyses make up a seemingly homogeneous group. A best fitted Discordia line yields a Concordia intercept age of $1789 \pm 8 \mathrm{Ma}$ while the ${ }^{207} \mathrm{~Pb}{ }^{206} \mathrm{~Pb}$ ages form a similar robust mean at $1790 \pm 6 \mathrm{Ma}(n=15,95 \%$ conf., $M S W D=0.91$ ). Either of these age calculations are valid.

\section{Discussion and conclusions}

Zircon is known to survive severe metamorphism, but can readily form secondary coating atop primary grains. Moreover, zircon seeds are assimilated during magma ascent, and relict zircon can survive from a continental provenance. Together these features result in a complex pattern of crystallizations within a single grain. Geologically significant ages are supposed to monitor an isotopically homogeneous part of a grain or set of grains. It is evident that these conditions are not always met with and this fact should be considered when comparing age figures obtained with different techniques and to different standards.

\section{I.Timing of the imbrication and overthrust in Torsholma}

The TIMS and SIMS datings of the rocks in the Torsholma area give us time constraints as follows. The emplacement age of the deformed orthogneiss, c. $1879 \pm 6 \mathrm{Ma}$, is comparable to the ages of the early gneissose granodioritic intrusions reported from southern Finland in this study (c. $1885 \mathrm{Ma}$, and summarised in Table 3) and in neighbouring regions of the Tampere Schist Belt (c. 1900-1880 Ma) and elsewhere (Kähkönen, 1999; Nironen et al., 2002). The studied area forms a sub-horizontal sequence of multiply folded supracrustal rocks and gneisses with structures (refolded folds in Fig. 12) indicating an early overturning and sub-horizontal thrusting of the attenuated and banded sequence towards the northwest. This phase of deformation conceivably correlates with the re- gional D2 deformation elsewere in SW Finland (Ehlers et al., 1993; Väisänen, 2002). That folding occurred well before the regional D3 phase, which is roughly synchronous with the intrusion of the migmatizing microcline granites within the LSGM zone. The deformed orthogneiss sequence was extended and intruded by roughly E-W directed mafic metadiabasic dykes (Fig. 2:1 and Fig. 3). The geological structure of the Torsholma area indicates a phase of extension of the crust, and intrusion of steep mafic dykes which took place after the strongly recumbent fold phases (D2), but before the subsequent stacking and imbrication of the gneiss slab between sub-horizontal sheets of mafic volcanics (Fig 2:3). Our disparate and rather limited SIMS zircon analyses from the amphibolite dykes (sample 00014) rendered an imprecise result of $1859 \pm 19 \mathrm{Ma}$ for the extensional phase following upon the subhorizontal D2-folding of the gneisses.

In the concept of a Svecofennian arc accretion, recently reviewed by Väisänen (2002), the formation of this rock collage would represent a significant phase of collision between the Southern (SSAC) and Central (CSAC) Svecofennian Arc Complexes. A sheet of granodiorite (sample A1261, 1861 $\pm 19 \mathrm{Ma}$ ) intruded the stack of previously imbricated rock slabs, between the deformed orthogneisses and the overlying outlier of amphibolite (Fig. 2:3). The granodiorite is moderately sheared (top towards NW, Fig. 13). Nearby, only slightly deformed granite dykes of similar age and composition (sample A1187 with an age of $1865 \pm 13 \mathrm{Ma}$ ) also transect the deformed orthogneisses. They seemingly belong to the same intrusion which apparently took place during the vaning stages of the collisional episode.

The emplacement of the orthogneisses at $1879 \pm 6 \mathrm{Ma}$ and the intrusion of the granodiorite dykes at $1865 \pm 13$ Ma brackets the time of intrusion of the amphibolite dykes (here dated poorly at $1859 \pm 19 \mathrm{Ma}$ ) into a rather narrow time frame (see Fig. 3). These dykes intruded during what is believed to be a late stage of the 


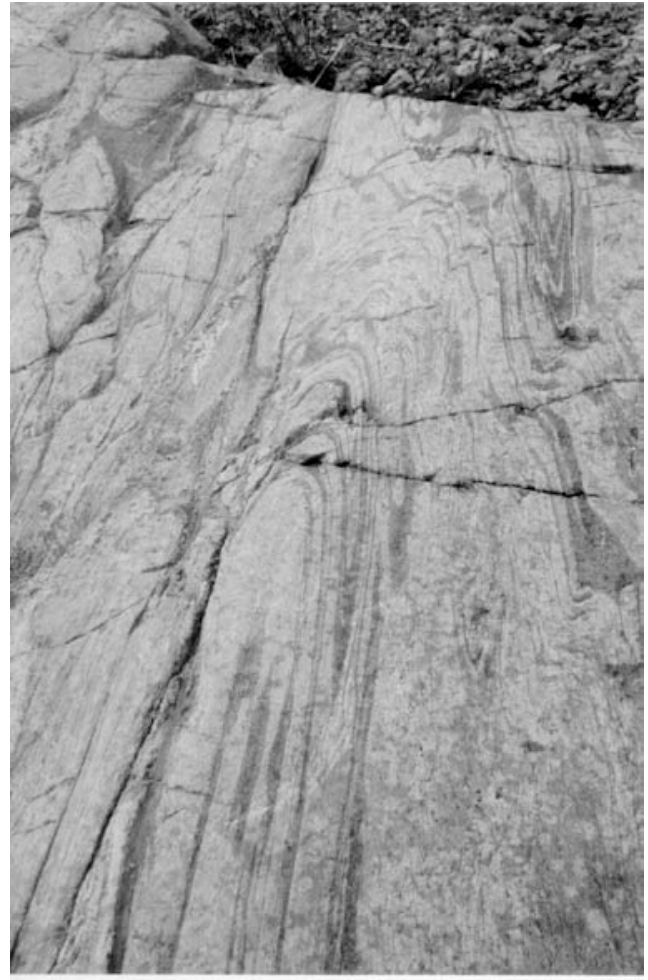

Fig. 12. Strongly deformed granodioritic gneiss with amphibolitic bands. The fold interference pattern indicates refolded strongly recumbent mesoscopic folds. The fold axes dip gently towards the observer (towards W). Locality at Torsholma.

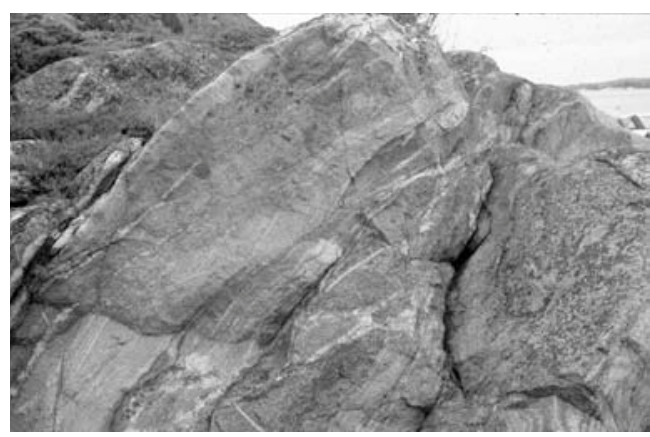

Fig. 13.Vertical outcrop of granodioritic gneiss intruding a stack of imbricated rock slabs. Shear lenses indicate displacement of the top towards the northwest. Locality at Räddarskär, Torsholma.

stacking and imbrication processes. On the other hand, the original emplacement of the older orthogneiss was followed by early deformation involving subhorizontal (D2) nappes and thrusting. The extension of the crust and the intrusion of the meta-diabases must have occurred between those two tectonic episodes. This leaves us with an approximate time interval of c. 1875-1860 Ma for the intrusion of the dykes and the subsequent phase of stacking and imbrication. This is in accordance with the estimation by Väisänen et al. (2002) for the accretion and collission between the SSAC and CSAC.

Both in the deformed orthogneisses (sample 98033) and in the cross cutting dykes of a latekinematic type granodiorite (sample A1187) there are monazites giving concordant ages of about $1830 \mathrm{Ma}$. The same age is observed from single grain SIMS spot analyses of zircon overgrowths in the same sample (Fig. 4). It is also the dominant age of the microcline granites belonging to the LSGM zone of southern Finland (Suominen, 1991; Kurhila et al., 2004), and conceivably this signifies an episode of elevated temperatures accompanying metamorphism and intrusion of these granites. The whole collage of rock slabs was later cut by a set of undeformed pegmatites indicating post-collisional collapse (Lindroos et al., 1996; Fig. 2:4) and yielding a concordant monazite age of $1795 \pm 4$ Ma (sample A1185).

\subsection{The age of the volcanics and the granodiorite of the Enklinge area}

The Enklinge area features well preserved subaqueous volcanic sequences earlier described by Sederholm (1934), Ehlers (1976), and Ehlers \& Lindroos (1990b). Sample 00013 is a rhyolite porphyry from the upper part of the stratigraphic secuence. It overlies a sequence of mafic and intermediate lavas and fragment-rich rocks. The precise SIMS U-Pb zircon age of $1885 \pm 5 \mathrm{Ma}$ reported here is in agreement with some of the published ages on volcanic rocks from the Svecofennian domain in Sweden and Finland (e.g., Kähkönen, 1999).

The surrounding granodioritic gneiss has a previously reported multi-grain ID-TIMS zircon age of $1882 \pm 15$ Ma (Suominen, 1991). 


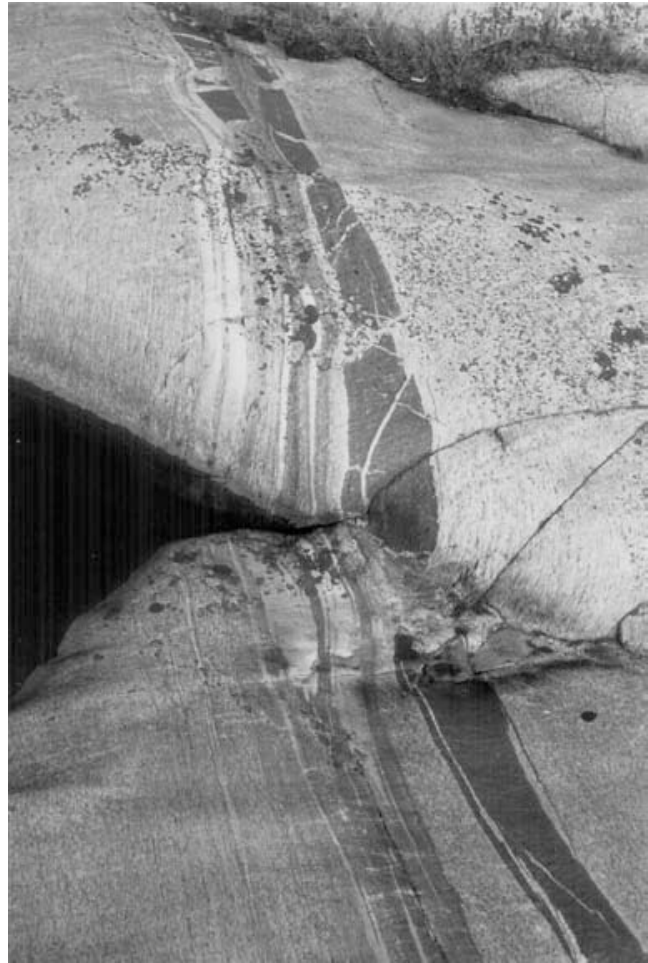

Fig 14. Amphibolitic meta-diabases are intrusive into gneissose granodiorite. The mafic dykes are deflected into the SFSZ shearzone and strongly deformed and transposed parallel to the direction of shearing. Locality at Rödgrund, Sottunga.

These rocks are younger and structurally discordant to the volcanics. However, because of their similar chemistry, and since several finegrained quartz porphyry dykes are subparallel with the rhyolitic volcanics, Ehlers and Lindroos (1990a) considered the dykes to be hypabyssal equivalents of the same magma. Our new sample 95020 represents a deformed part of the granodioritic gneisses and yields a SIMS zircon age of $1884 \pm 3 \mathrm{Ma}$. This corraborates previous deductions on the close relationship in time and space between the extrusion of the Enklinge volcanics and the intrusion of the surrounding granodiorite. More importantly, there is a superb age agreement between these volcanics and our present SIMS results from the granodioritic gneisses of the Sottunga, Kökar and Torsholma areas (Table 3).

\subsection{The South Finland Shear Zone (SFSZ),}

The SFSZ represents a major zone of deformation that can be followed along the south coast of Finland for a couple of hundred kilometres. In its SW part this zone closely follows the contact of the LSGM zone (Fig. 1), but most of the deformation is in the older granodiorite-tonalite rocks representing early Svecofennian intrusions. Previous ID-TIMS age determinations from these rocks around Sottunga and Kökar cover an approximate age interval of c. 1870 $1895 \mathrm{Ma}$ (Suominen, 1991). Our new SIMS samples from the strongly banded gneisses on Sottunga and from the deformed tonalites-granodiorites on Kökar both indicate an intrusion age of $1884 \pm 5 \mathrm{Ma}$. The presence of older Palaeoproterozoic and Archaean zircons may explain why some published ages probably represent mixed populations.

The gneisses in the area along the SFSZ are intruded by swarms of amphibolitic metadiabase dykes (Fig. 14) reminiscent of those which appear on Torsholma. This is probably a regional feature which in most cases is obliterated by the later phases of metamorphism and granite intrusions within the LSGM zone. Since the dykes are deflected, they intruded the gneisses previous to the shearing along the SFSZ. In all likelihood, the intrusion of these mafic dykes is comparable to those on Torsholma and supplies a maximum age of the shearing that post-dates c. $1865 \mathrm{Ma}$.

The NW end of the SFSZ around the island of Sottunga is characterized by numerous granitic dykes forming a network discordantly crosscutting the shear zone. The granite dykes, however, have a schistosity (Edelman, 1979) and show minor deformation and deflection suggesting intrusion during the vaning stages of the shearing. Our SIMS sample (00010) from one of the late granite dykes in the NW part of the shear zone gives an age of $1790 \pm 6 \mathrm{Ma}$ and indicates the time of the last major activities along the zone in this area. On the northern shore of the island of Sottunga, the SFSZ is cut 
by the essentially undeformed Mosshaga granite with a U-Pb TIMS zircon age of $1788 \pm 11 \mathrm{Ma}$ (Welin et al., 1983). Thus our SIMS dated granite dykes in the NW end of the SFSZ are of the same age and extend from the Mosshaga granite massif some 10 kilometres along the shear zone. The coherence is also noted from petrographical and chemical analyses of both dykes and the Mosshaga pluton (e.g., Branigan, 1987).

\subsection{Regional considerations within the Svecofennian domain}

Prominent volcanism and igneous activity constitute timely separated episodes in the build-up of the Svecofennian domain. The granodioritic gneisses at Kökar with a zircon SIMS intrusion age of $1884 \pm 3 \mathrm{Ma}$ apparently contain significant proportions of continental crust that was formed just before $2000 \mathrm{Ma}$ ago (Fig. 5). Similarly, there are a number of $2.1-1.95 \mathrm{Ga}$ old zircons in Svecofennian metasedimentary rocks from central Finland (Huhma et al., 1991; Claesson et al., 1993; Lahtinen et al., 2002). However, Vaasjoki et al. (2003) have demonstrated that at least some of the c. 1920 Ma granitoids from central Finland do not contain inherited zircons. Scarce occurrences of rocks close to this age or somewhat older have been identified from central Sweden (c. 1.95 Ga granitoids, Wasström, 1996) while similar ages by Welin et al. (1993) and Lundqvist et al. (1998) run the possibility of including inherited grains. About 1.98-2.0 Ga old detrital zircon grains from south-central Finland show both pre-and post-sedimentary metamorphism older than previously recorded in the Svecofennian domain (Rutland et al., 2004). Moreover, Rutland et al. (2001a and b) demonstrate the existence of deformation structures in some Palaeoproterozoic supracrustal rocks of the Bothnian Basin from central Sweden that are not found elsewhere. They further postulate (op. cit.) the existence of a rifting continent making up the basement to the supracrustal rocks in regions like Bergslagen and south of the Skellefte district with continuations to Finland. A time concept involving c. 2 Ga old micro-continents originally distant to the Archaean regions in the NE has recently been proposed by Nironen et al. (2002) and Lahtinen et al. (2002). Although many Svecofennian granitoids are known to contain heterogeneous zircon populations (eg. Vaasjoki et al., 1996), the Kökar gneiss is seemingly the first case where inheritance from c. 2.0 Ga sources has been unequivocally demonstrated in a syntectonic Svecofennian intrusive rock. Thus, increasing evidences for the exitence of a Palaeoproterozoic continental crust before 1.93 $\mathrm{Ga}$ are accumulating.

The oldest well-constrained age of early magmatism from the Tampere region is c. $1904 \pm 4$ Ma (Kähkönen, 1999). The rock interfingers surrounding supracrustals which sometimes have been paralleled with the $\mathrm{Ha}$ veri, and Vammala belts (Kähkönen \& Nironen, 1994). Magmatism and deposition alternate to about $1880 \mathrm{Ma}$ when subsequent metamorphism and folding took place in central Finland. Towards west in the Bergslagen region of Sweden, magmatism and alternating sedimentation are observed in the approximate time interval 1904-1890 Ma (Allen et al., 1996; Lundstöm et al., 1998; Persson \& Persson, 1999). In comparison, the oldest magmatism in the Åland region is somewhat younger than that of both the Tampere and the Bergslagen region. There are so far no modern age determinations from Åland indicating granitoid emplacement ages in excess of $1890 \mathrm{Ma}$.

The earliest metamorphism in the Tampere schist belt commenced at about $1880 \mathrm{Ma}$, while the metamorphism of the allochthonous gneiss slab of Torsholma is seemingly later. Metamorphic ages of about $1860 \mathrm{Ma}$ have been documented from zircon overgrowths and monazites within the Bothnian Basin near the Skellefte district (Rutland et al., 2001b). The comparable metamorphic episode in the Bergslagen region is so far limited to be younger than the c. 1856 Ma old deformed pegmatites at Stora Vika (Welin \& Stålhös, 1986). 
Table 3. Summary of calculated ages, where some indicate rock formation/emplacement, others assimilated crust or metamorphic events.

\begin{tabular}{|c|c|c|c|c|}
\hline $\begin{array}{l}\text { Sample } \\
\text { No }\end{array}$ & Rock type and location/mineral & Technique & $\begin{array}{c}\text { No. of } \\
\text { analyses }\end{array}$ & $A g e \pm 2 s(M a)$ \\
\hline A1 185 & $\begin{array}{l}\text { Torsholma, Hummelholm } \\
\text { pegmatite/monazite }\end{array}$ & TIMS & 1 & $1795 \pm 4$ \\
\hline LIG00014 & Torsholma metadiabase/zircon & SIMS & 7 & $1859 \pm 19$ \\
\hline A1 187 & $\begin{array}{l}\text { Torsholma, Bockholm, } \\
\text { granodiorite dyke/zircon/ } \\
\text { monazite }\end{array}$ & $\begin{array}{l}\text { TIMS } \\
\text { TIMS }\end{array}$ & $\begin{array}{l}\text { Multi } \\
1\end{array}$ & $\begin{array}{l}1865 \pm 7 \\
1827 \pm 4\end{array}$ \\
\hline A1261 & $\begin{array}{l}\text { Torsholma, Räddarskär, } \\
\text { granodiorite/zircon }\end{array}$ & TIMS & Multi & $1861 \pm 19$ \\
\hline A1334 & $\begin{array}{l}\text { Torsholma, Gräsören, } \\
\text { granulite/zirc } \\
\text { /monazite }\end{array}$ & $\begin{array}{l}\text { TIMS } \\
\text { TIMS }\end{array}$ & $\begin{array}{l}\text { Multi } \\
1\end{array}$ & $\begin{array}{l}1867 \pm 15 \\
1829 \pm 5\end{array}$ \\
\hline LIG98033 & $\begin{array}{l}\text { Torsholma, granulite, Lilla Hummelholm } \\
\text { /zircon } \\
\text { /zircon } \\
\text { /monazite }\end{array}$ & $\begin{array}{l}\text { SIMS } \\
\text { SIMS } \\
\text { TIMS }\end{array}$ & $\begin{array}{l}8 \\
2 \\
3\end{array}$ & $\begin{array}{l}1879 \pm 6 \\
\text { c. } 1828 \\
\text { c. } 1830\end{array}$ \\
\hline LIG95020 & $\begin{array}{l}\text { Enklinge, Gräshäran, } \\
\text { granodiorite/zircon } \\
\text { /xenocrystic zircon }\end{array}$ & $\begin{array}{l}\text { SIMS } \\
\text { SIMS }\end{array}$ & $\begin{array}{l}8 \\
1\end{array}$ & $\begin{array}{ll} & 1884 \pm 3 \\
\text { c. } 2061\end{array}$ \\
\hline LIG00013 & Enklinge, Rhyolite/zircon & SIMS & 16 & $1885 \pm 6$ \\
\hline LIG99021 & $\begin{array}{l}\text { Kökar, breccia in banded gneiss } \\
\text { Hellsö } \\
\text { /zircon } \\
\text { /xenocrystic zircon } \\
\text { /oldest xenocrystic zircon } \\
\text { /zircon (a few grains) }\end{array}$ & $\begin{array}{l}\text { SIMS } \\
\text { SIMS } \\
\text { SIMS } \\
\text { TIMS }\end{array}$ & $\begin{array}{l}16 \\
7 \\
1 \\
3\end{array}$ & $\begin{array}{l}1884 \pm 3 \\
\text { c. } 2040 \\
\text { c. } 3163 \\
1889 \pm 3\end{array}$ \\
\hline LIG99022 & $\begin{array}{l}\text { Kökar, granodioritic gneiss, } \\
\text { Hellsö/zircon } \\
\text { /titanite }\end{array}$ & $\begin{array}{l}\text { TIMS } \\
\text { TIMS }\end{array}$ & $\begin{array}{l}1 \\
3\end{array}$ & $\begin{array}{l}1891 \pm 2 \\
\text { c. } 1785\end{array}$ \\
\hline LIG99024 & Sottunga, banded gneiss/zircon & SIMS & 19 & $1884 \pm 5$ \\
\hline LIG00010 & $\begin{array}{l}\text { Sottunga granite dyke/zircon } \\
\text { Hästnäs dyke/xenocryst. zircon }\end{array}$ & $\begin{array}{l}\text { SIMS } \\
\text { SIMS }\end{array}$ & $\begin{array}{l}15 \\
1\end{array}$ & $\begin{array}{l}1789 \pm 8 \\
\text { c. } 2033\end{array}$ \\
\hline
\end{tabular}

Metamorphic imprint at about $1830 \mathrm{Ma}$ in the LSGM zone (Ehlers et al., 1993) is also recorded by concordant monazite ages and overgrowths on zircons in several samples from Torsholma. This episode is confined to this zone and is not observed elsewhere in the Svecofennian domain. It represents episodes of metamorphism, remelting and formation of migmatitic granites. However, granite intrusions of approximately the same age occur as an older part in the Transscandinavian Igneous Belt that bor- ders the Svecofennian domain to the south and west.

\section{Concluding remarks}

The volcanic extrusions at Enklinge $(1885 \pm 6$ $\mathrm{Ma}$ ) are coeval with the intrusion of the gneissose granodiorites in the surrounding areas of Enklinge, Sottunga and Kökar. These rocks yield remarkably coherent SIMS ages with an average of about $1885 \pm 5 \mathrm{Ma}$ (Table 3 ). They in- 
dicate a major episode of Svecofennian volcanism and crustal formation over large areas. An older population of zircon grains in the granodiorites cluster at around $2040 \mathrm{Ma}$, in agreement with similar indications from mainly metasedimentary rocks in other areas of S. Finland and Sweden.

The medium- to fine-grained granite dykes along the NW end of the South Finland Shear Zone (SFSZ) register the last displacements along the zone. The dykes are discordant in relation to the strongly deformed granodiorites but are themselves schistose and gently folded. Their age of c. $1790 \mathrm{Ma}$ dates the later stages of shearing along the SFSZ. Petrologically and chemically they are similar to the Mosshaga intrusion which transects the SFSZ close to the Åland Rapakivi (Fig. 1). The dykes stretch about $10 \mathrm{~km}$ southwards along the shear zone, thus substantiating their close relationship in time to the developments within the SFSZ.

The collage of thin imbricated rock slabs in the Torsholma area separates two stages of intrusions, at c. 1880 and c. $1865 \mathrm{Ma}$, in the supracrustal rocks. Gneisses of the older group are sheared and folded together with the supracrustals into subhorizontal recumbent folds which are subsequently refolded (Fig. 2 ). The episodes of folding are followed by an extensional stage producing a set of steeply dipping metadiabase dykes. The whole collage is subsequently overthrusted and sandwiched between pillowed mafic lava layers. This episode can be interpreted as a result of a collisional episode (accretion and collision between SSAC and CSAC, Väisänen, 2002 and references therein).

The c. $1865 \mathrm{Ma}$ granodiorites intrude the sandwiched layers as gently dipping sheets and steep dykes in a late stage of this collisional deformation, and they still show traces of "top towards W" movements (Fig. 13). These events supply a rather limited time interval for the most intensive part of the Svecofennian deformational history. They suggest that the main collisional episode, as shown by overthrusting, imbrication and metamorphism, probably took place some 1860-1875 Ma ago. Thereafter, basaltic dyke intrusions mark an episode of crustal extension. Väisänen (2002) suggests an age of c. $1870 \mathrm{Ma}$ for this collisional stage based on the assumption that this is the youngest true recorded age of the early Svecofennian granodioritic intrusions.

In several samples of the Torsholma granodiorites, monazite crystallizations and zircon overgrowths yield concordant $\mathrm{U}-\mathrm{Pb}$ ages of approximately $1830 \mathrm{Ma}$. This age is in a general accordance with the ages of granites and migmatites in the LSGM zone (Ehlers et al., 1993). Potassium granites belonging to this group occur all over the research area in Torsholma, and the monazites most probably record the overprinting temperature anomaly of this phase in the structural evolution of southern Finland.

A steep undeformed pegmatite dyke with a monazite age of $1795 \pm 4 \mathrm{Ma}$ transects the whole set of imbricated rock slabs in Torsholma (Fig. 2). The overlapping U-Pb ages of this and other pegmatites (Lindroos et al., 1996) of the postkinematic type intrusions, as well as the timing of the large-scale shear zones, indicate consolidation of the Svecofennian crust. This also suggests that deformation was partitioned along steep discrete crustal shears in contrast to the earlier subhorizontal crustal shortening and thickening seen in the Torsholma area. The transition between the earlier tectonic history of ductile subhorizontal collisional crustal deformation, and the later phases of brittle strain partitioning into steeply dipping shears must have taken place after the intrusion of the subhorizontal granite sheets (c. $1830 \mathrm{Ma}$ ) belonging to the LSGM zone of southern Finland.

\section{Acknowledgements}

We are grateful to Roland Gorbatschev (Lund), Yrjö Kähkönen (Helsinki) and Aulis Kärki (Oulu) for their thorough and helpful reviews. We thank the staff in the Isotope Geology units of the Finnish Geological Survey (GTK), the Swedish Museum of Natural History (NRM), and in particular Martin Whitehouse and Lev Ilyinsky of the NORDSIM laboratory, for assistance during different stages of sample preparation, analysis 
and data reduction. This is contribution \#107 of the NORDSIM laboratory which is a joint Nordic facility in Stockholm sponsored by the research councils, the GTK and the NRM. We also thank Pernilla Lindroos, Anna Rikberg and Taija Torvela for mapping field relations in the Åland archipelago during their time at Åbo Akademi University $(\AA A)$. Part of this study was carried out during a professorship to T. Skiöld at $\AA$ A from the Nordic Academy for Advanced Study, Oslo.

\section{Editorial handling: Petri Peltonen}

\section{References}

Allen, R.L., Lundström, I., Ripa, M., Simeonov, A. \& Christoffersson, H., 1996. Facies analysis of a 1.9 Ga, continental margin, back-arc, felsic caldera province with diverse $\mathrm{Zn}-\mathrm{Pb}-\mathrm{Ag}-(\mathrm{Cu}-\mathrm{Au})$ sulfide and $\mathrm{Fe}$ oxide deposits, Bergslagen region, Sweden. Economic Geology 91, 979-1008.

Branigan, N.P., 1987. The role of shearing in the Proterozoic development of the Alland Archipelago, SW Finland. Bulletin of the Geological Society of Finland 59, 117-128.

Claesson, S., Huhma, H., Kinny, P.D. \& Williams, I.S., 1993. Svecofennian detrital zircon ages-implications for the Precambrian evolution of the Baltic Shield. Precambrian Research 64, 109-130.

Edelman, N., 1979. Schistosity of cutting pegmatites and its relation to the fold phases in Sälsö, southwestern Finland. Bulletin of the Geological Society of Finland $51,11-16$.

Edelman, N. \& Jaanus-Järkkälä, M., 1983. A plate tectonic interpretation of the Precambrian of the archipelago of SW Finland. Geological Survey of Finland, Bulletin 325, 4-33.

Ehlers, C., 1976. Homogeneous deformation in Precambrian supracrustal rocks of Kumlinge area, SW Finland. Precambrian Research 3, 481-504.

Ehlers, C \& Lindroos, A., 1990a. Low angle ductile shears in the early proterozoic rocks of SW Finland. Geologiska Föreningen i Stockholm Förhandlingar 112, 177-178.

Ehlers, C. \& Lindroos, A., 1990b. Early Proterozoic Svecofennian volcanism and associated plutonism in Enklinge, SW Finland. Precambrian Research 47, 307-318.

Ehlers, C. \& Lindroos, A., 1997. Stratigraphy and structural evolution of the early Proterozoic Svecofennian rocks of south Finland. In: Rutland, R.W.R. \& Drummond, B.J. (eds.) Palaeoproterozoic Tectonics and Metallogenesis: comparative analysis of parts of the Australian \& Fennoscandian shields. AGSO Record $1997 / 44$, 43-45.

Ehlers, C., Lindroos, A. \& Selonen, O., 1993. The late Svecofennian granite-migmatite zone of southern Finland-a belt of transpressive deformation and granite emplacement. Precambrian Research 64, 295-309.

Elliott, B.A., Rämö, O.T. \& Nironen, M., 1998. Mineral chemistry constraints on the evolution of the 1.88$1.87 \mathrm{Ga}$ post-kinematic granite plutons in the Central Finland Granitoid Complex. Lithos 45, 109-129.
Elming, S-A. \& Mattsson, H., 2001. Post Jotnian basic intrusions in the Fennoscandian Shield and the break up of Baltica from Laurentia: a paleomagnetic and AMS study. Precambrian Research 108, 215-236.

Gaál, G. \& Gorbatschev, R., 1987. An outline of the Precambrian evolution of the Baltic Shield. Precambrian Research 35, 15-52.

Hoffman, P.E., 1989. Precambrian geology and tectonic history of North America. In: Bally, A.W. and Palmer, A.R. (eds.) The Geology of North America-An Overview. Geological Society of America., Boulder, Colorado, 447-512.

Huhma, H., Claesson, S., Kinny, P.D. \& Williams, I.S., 1991. The growth of early Proterozoic crust: new evidence from Svecofennian detrital zircons. Terra Nova $3,175-179$.

Kähkönen, Y. 1999. Stratigraphy of the central parts of the Palaeoproterozoic Tampere Schist Belt, southern Finland: review and revision. Bulletin of the Geological Society of Finland 71, 13-29.

Kähkönen, Y. \& Nironen, M., 1994. Supracrustal rocks around the Palaeoproterozoic Haveri Au-Cu deposit, southern Finland: Evolution from a spreading center to a volcanic arc environment. Geological Survey of Finland Special Paper 19, 141-159.

Karlström, K.E., Åhäll, K., Harlan, S.S., Williams, M.L., McLelland, J. \& Geissman, J.W., 2001. Long-lived $(1.8-1.0 \mathrm{Ga})$ convergent orogen in southern Laurentia, its extensions to Australia and Baltica, and implications for refining Rodinia. Precambrian Research $111,5-30$.

Korsman, K., Korja, T., Pajunen, M. \& Virransalo, P. \& GGT/SVEKA Working Group, 1999. The GGT/ SVEKA Transect: Structure and evolution of the continental crust in the Palaeoproterozoic Svecofennian orogen in Finland. International Geology Review 41, 287-333.

Krogh, T.E., 1982. Improved accuracy of U-Pb zircon ages by the creation of more concordant systems using an air abrasion technique. Geochimica et Cosmochimica Acta 46, 637-649.

Kurhila, M., Vaasjoki. M., Mänttäri, I., Rämö, T. \& Nironen, M. 2004. Conventional and ion probe U-Pb age results on the lateorogenic microcline granites in southern Finland. The $26^{\text {th }}$ Nordic Geological Winter Meeting, Uppsala, Sweden. GFF 126, p. 27.

Lahtinen, R., 1996. Geochemistry of Palaeoproterozoic supracrustal and plutonic rocks in the Tampere-Hämeenlinna area, Southern Finland. Geological Survey of Finland, Bulletin 389, 113 p.

Lahtinen, R. \& Huhma, H., 1997. Isotopic and geochemical constraints on the evolution of the 1.93-1.79 Ga Svecofennian crust in Finland. Precambrian Research $82,13-34$.

Lahtinen, R., Huhma, H. \& Kousa, J., 2002. Contrasting source components of the Paleoproterozoic Svecofennian metasediments: Detrital zircon U-Pb, SmNd and geochemical data. Precambrian Research 116, 81-109.

Lahtinen, R., Korja, A. \& Nironen, M., 2004. Paleoproterozoic orogenic evolution of the Fennoscandian shield at 1.92-1.77 Ga - the formation of a supercontinent. The $26^{\text {th }}$ Nordic Geological Winter Meeting, Uppsala, Sweden. GFF 126, p. 27. 
Lindh, A., Andersson, U.B., Lundqvist, T. \& Claesson, S., 2001. Evidence of crustal contamination of mafic rocks associated with rapakivi rocks: an example from the Nordingrå complex Central Sweden. Geological Magazine 138, 371-386.

Lindroos, A., Romer, R., Ehlers, C. \& Alviola, R., 1996. Late-orogenic Svecofennian deformation in SW Finland constrained by pegmatite emplacement ages. Terra Nova $8,567-574$.

Lundström, I., Allen, R.L., Persson, P-O. \& Ripa, M., 1998. Stratigraphies and depositional ages of Svecofennian, Palaeoproterozoic metavolcanic rocks in E. Svealand and Bergslagen, south central Sweden. GFF 120, 315-320.

Ludwig, K.R. 1991.PBDAT: A computer program for processing U-Pb-Th data.Version 1.20. United States Geological Survey, Open File Report 88-542.

Lundqvist, T., Vaasjoki, M. \& Persson, P-O., 1998. U-Pb ages of plutonic and volcanic rocks in the Svecofennian Bothnian Basin, central Sweden, and their implications for the Palaeoproterozoic evolution of the Basin. GFF 120, 357-363.

Nironen, M., 1997. The Svecofennian Orogen: a tectonic model. Precambrian Research 86, 21-44.

Nironen, M., Korja, A., Lahtinen, R. \& Tuisku, P., 2000. Crustal boundaries of East European Craton-Keys to Proterozoic amalgamation. In: Pesonen, L. et al. (eds.) Lithosphere 2000, A symposium on the structure, composition and evolution of the lithosphere in Finland. Programme and extended abstracts. Institute of Seismology, University of Helsinki, Report S41, 121-128.

Nironen, M., Lahtinen, R. \& Korja, A., 2002. Palaeoproterozoic tectonic evolution of the Fennoscandian shield-comparison to modern analogues. In: Lahtinen, R. et al. (eds.) Lithosphere 2002, Second symposium on the structure and evolution of the lithosphere in Finland. Programme and extended abstracts. Institute of Seismology, University of Helsinki, Report S-42, 95-97.

Persson, L. \& Persson, P-O., 1999. U-Pb zircon age of the Vätö granite, south central Sweden. In Bergman, S. (ed.): Radiometric dating results, 3. Division of Bedrock Geology, Geological Survey of Sweden ser. C 831, 91-99.

Rutland, R.W.R., Kero, L., Nilsson, G. \& Stölen, L.K., 2001a. Nature of a major tectonic discontinuity in the Svecofennian province of northern Sweden. Precambrian Research 112, 211-237.

Rutland, R.W.R., Skiöld, T. \& Page, R.W., 2001b. Age of deformation episodes in the Palaeoproterozoic domain of northern Sweden, and evidence for a pre-1.9 Ga crustal layer. Precambrian Research 112, 239-259.

Rutland, R.W.R., Skiöld, T. \& Kero, L., 2003. Reply to a discussion by Pär Weihed. Precambrian Research 121, 149-153.

Rutland, R.W.R., Williams, I.S. \& Korsman, K., 2004. Pre-1.91 Ga deformation and metamorphism in the Palaeoproterozoic Vammala Migmatite Belt, southern Finland, and implications for Svecofennian tectonics. Bulletin of the Geological Society of Finland 76, 93-140.

Sederholm, J.J., 1934. On migmatites and associated precambrian rocks of southwestern Finland. Part III. The Åland Islands. Bulletin de la Commission géologique de Finlande 107, 68 p.
Suominen, V., 1991. The chronostratigraphyof southwestern Finland with special reference to Postjotnian and Subjotnian diabases. Geological Survey of Finland, Bulletin 365, $100 \mathrm{p}$.

Stacey, J.S. \& Kramers, J.D., 1975, Approximation of the terrestrial lead isotope evolution by a two-stage model. Earth and Planetary Science Letters 26, 207-221.

Torvela, T., Stålfors, T. \& Ehlers, C., 2003. The South Finland Shear Zone-Crustal scale ductile shearing of the Palaeoproterozoic crust in SW Finland. In: Deformation Mechanics, Rheology and Tectonics. St. Malo France April 14-16, 2003, Abstracts, p. 162.

Vaasjoki, M., Rämö, O.T. \& Sakko, M., 1991. New U-Pb ages from the Wiborg rapakivi area: constraints on the temporal evolution of the rapakivi granite-anorthositediabase dyke association of southwestern Finland. Precambrian Research 51, 227-243.

Vaasjoki, M., Pietikäinen, K. \& Vaarma, M., 1996. U$\mathrm{Pb}$ zircon determinations from the Keikyä breccia and other sites in the Svecofennides: indications of a Svecokarelian protocrust. Bulletin of the Geological Society of Finland 68, 3-10.

Vaasjoki, M., Kärki, A. \& Laajoki, K., 2001. Timing of Palaeoproterozoic Crustal shearing in the central Fennoscandian Shield according to U-Pb data from associated granitoids, Finland. Bulletin of the Geological Society of Finland 73, 87-101.

Vaasjoki, M., Huhma, H., Lahtinen, R. \& Vestin, J., 2003. Sources of Svecofennian granitoids in the light of ion probe $\mathrm{U}-\mathrm{Pb}$ measurements on their zircons. Precambrian Research 121, 251-262.

Väisänen, M., 2002. Tectonic evolution of the Palaeoproterozoic Svecofennian Orogen in Southwestern Finland. Annales Universitatis Turkuensis, ser. AII, Tom 154, $21 \mathrm{p}$.

Väisänen, M., Mänttäri, I. \& Hölttä, P., 2002. Svecofennian magmatic and metamorphic evolution in SW Finland as revealed by U-Pb zircon SIMS geochronology. Precambrian Research 116, 111-127.

Wasström, A., 1996. U-Pb zircon dating of a quartzfeldspar porphyritic dyke in the Knaften area, Västerbotten County, northern Sweden. In: Lundqvist, Th. (ed.) Radiometric dating results 2. Geological Survey of Sweden ser. C 828, 34-40.

Weihed, P., Billström, K., Persson, P-O. \& Bergman Weihed, J., 2002. Relationship between 1.90-1.85 Ga accretionary processes and $1.82-1.80 \mathrm{Ga}$ oblique subduction at the Karelian craton margin, Fennoscandian Shield. GFF 124, 163-180.

Welin, E. \& Stålhös, G., 1986. Maximum age of the synmetamorphic Svecokarelian fold phases in south central Sweden. Geologiska Föreningens i Stockholm Förhandlingar 108, 31-34.

Welin, E., Christiansson, K., \& Kähr, A-M., 1993. Isotopic investigations of metasedimentary and igneous rocks in the Palaeoproterozoic Bothnian Basin, central Sweden. Geologiska Föreningens i Stockholm Förhandlingar 115, 285-296.

Welin, E., Vaasjoki, M. \& Suominen,V., 1983. Age differences between $\mathrm{Rb}-\mathrm{Sr}$ whole rock and U-Pb zircon ages of syn- and postorogenic Svecokarelian granitoids in Sottunga, SW Finland. Lithos 16, 297-305. 
